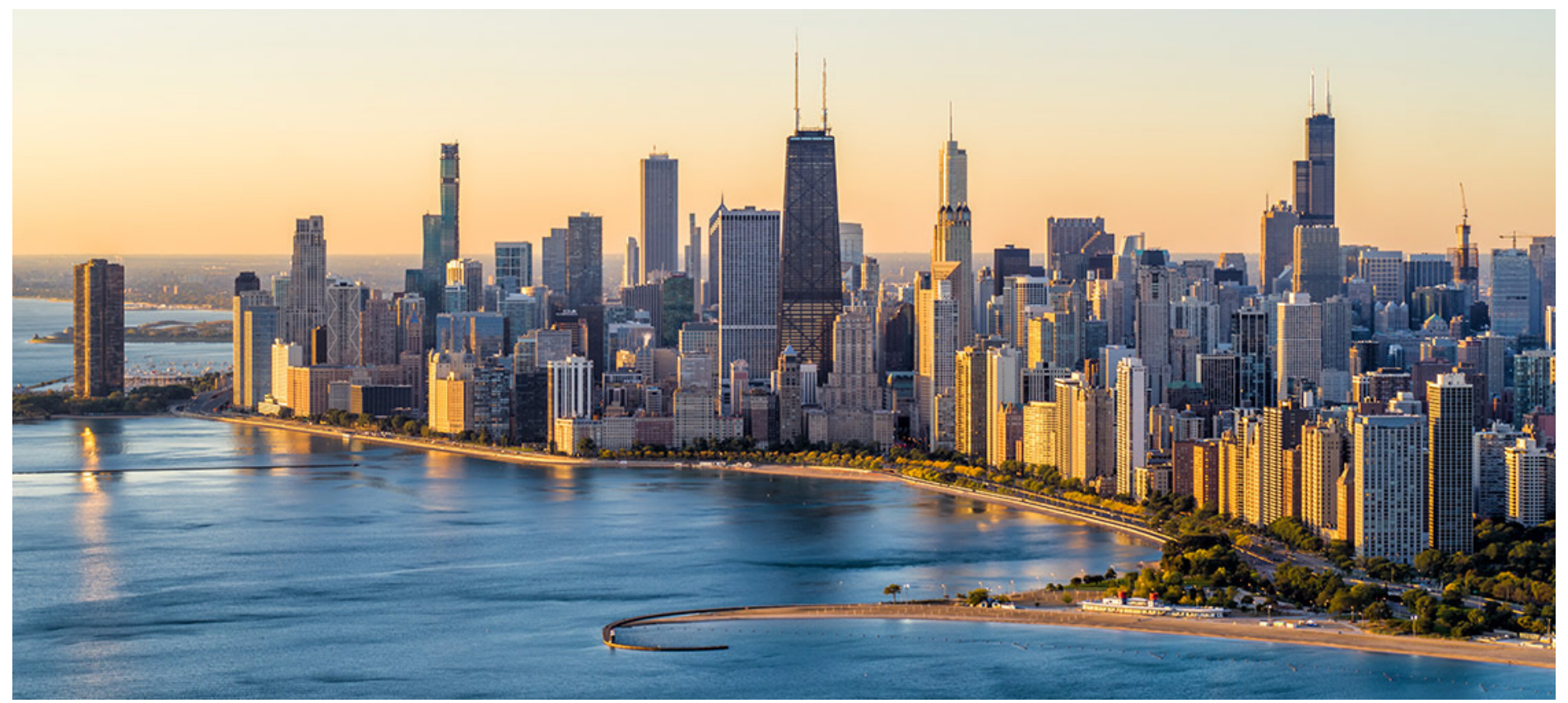

\title{
Performance Evaluation of Three RTU Energy Efficiency Technologies
}

Korbaga Woldekidan, Daniel Studer, and Ramin Faramarzi

Produced under direction of ComEd by the National Renewable Energy Laboratory (NREL) under Technical Services Agreement TSA-19-01159

NREL is a national laboratory of the U.S. Department of Energy Office of Energy Efficiency \& Renewable Energy

Operated by the Alliance for Sustainable Energy, LLC

This report is available at no cost from the National Renewable Energy Laboratory (NREL) at www.nrel.gov/publications.
Strategic Partnership Project Report NREL/TP-5500-75551

December 2020 


\title{
Performance Evaluation of Three RTU Energy Efficiency Technologies
}

\author{
Korbaga Woldekidan, Daniel Studer, and Ramin Faramarzi
}

Produced under direction of ComEd by the National Renewable Energy Laboratory (NREL) under Technical Services Agreement TSA-19-01159

\section{Suggested Citation}

Woldekidan, Korbaga, Daniel Studer, and Ramin Faramarzi. 2020. Performance Evaluation of Three RTU Energy Efficiency Technologies. Golden, CO: National Renewable Energy Laboratory. NREL/TP-5500-75551. https://www.nrel.gov/docs/fy21osti/75551.pdf.

NREL is a national laboratory of the U.S. Department of Energy Office of Energy Efficiency \& Renewable Energy Operated by the Alliance for Sustainable Energy, LLC

This report is available at no cost from the National Renewable Energy Laboratory (NREL) at www.nrel.gov/publications.

Contract No. DE-AC36-08GO28308
Strategic Partnership Project Report NREL/TP-5500-75551

December 2020

National Renewable Energy Laboratory 15013 Denver West Parkway Golden, CO 80401

303-275-3000 • www.nrel.gov 


\section{NOTICE}

This work was authored by the National Renewable Energy Laboratory, operated by Alliance for Sustainable Energy, LLC, for the U.S. Department of Energy (DOE) under Contract No. DE-AC36-08GO28308. Support for the work was also provided by ComEd through CLEAResult under TSA-19-01159. The views expressed in the article do not necessarily represent the views of the DOE or the U.S. Government.

The ComEd Energy Efficiency Program is funded in compliance with state law.

This report is available at no cost from the National Renewable Energy Laboratory (NREL) at www.nrel.gov/publications.

U.S. Department of Energy (DOE) reports produced after 1991 and a growing number of pre-1991 documents are available free via www.OSTI.gov.

Cover photo from iStock 1180689542.

NREL prints on paper that contains recycled content. 


\section{Acknowledgments}

The authors would like to thank the ComEd Energy Efficiency Program and CLEAResult for supporting this research. This report was prepared by the National Renewable Energy Laboratory Building Technologies and Science Center.

The authors would also like to express their sincere gratitude to Matthew Dahlhausen and Adam Hirsch for their in-depth report review, Grant Wheeler for providing rooftop unit (RTU) performance data and advising on control strategies for two-stage and variable-speed RTUs, and Ryan Meyer for his support in advising OpenStudio ${ }^{\circledR}$ measures development.

For more information, contact:

Korbaga Woldekidan

National Renewable Energy Laboratory

Email: Korbaga.Woldekidan@nrel.gov 


\section{List of Acronyms}

$\mathrm{AC}$

BHP

$\mathrm{DC}$

DOE

HVAC

IEER

NREL

RTU

SCE

SRM

VFD

WC air conditioning

brake horsepower

direct current

U.S. Department of Energy

heating, ventilating, and air conditioning

integrated energy efficiency ratio

National Renewable Energy Laboratory

rooftop unit

Southern California Edison

switched reluctance motor

variable frequency drive

water column 


\section{Executive Summary}

This project was part of an effort by ComEd to evaluate the energy saving potential of emerging technologies in the Chicago area. This project focused on the evaluation of energy and peak demand savings potentials of emerging technologies related to rooftop units (RTUs).

According to the Commercial Building Energy Consumption Survey, close to $52 \%$ of commercial buildings use packaged air conditioning units like RTUs for providing space cooling (U.S. Energy Information Administration 2012). Even if ANSI/ASHRAE/IES Standard 90.1-2016 requires directexpansion units with cooling capacity greater than $110,000 \mathrm{Btu} / \mathrm{h}$ to have either two-speed or variablespeed fan control, the majority of installed RTUs employ single- or two-stage compressors with a constant-speed supply fan (Cai and Braun 2018).

Recently, RTUs with variable-speed compressors and variable-speed fans with an improved efficiency have become available on the market. In addition to their improved efficiency, their ability to modulate their speed as needed can reduce short cycling issues. However, more research is needed to quantify their energy savings potential for different building types as well as different geographic locations.

This study considered three technology upgrades to a baseline RTU with a single-stage compressor and constant-speed supply fan. EnergyPlus ${ }^{\circledR}$, the U.S. Department of Energy's (DOE's) building simulation platform, was used for evaluation of the technologies. Energy savings were estimated for six different building types: stand-alone retail, small office, strip mall, warehouse, fast-service restaurant, and fullservice restaurant. The savings estimations were based on Typical Meteorological Year 3 (TMY3) weather data for Chicago. Technology upgrades simulated included:

- Replacing the single-speed compressor with a two-stage compressor and adding a variable frequency drive (VFD) to the supply fan

- Replacing the single-speed compressor with a variable-speed compressor and adding a VFD to the supply fan

- Replacing the constant-speed induction motor of the supply fan with a high rotor pole switched reluctance motor $(\mathrm{SRM})$.

The simulation results revealed that upgrading the RTU with a variable-speed compressor and SRM supply fan can result in annual energy savings from 3\% to $23 \%$. Among the building types, the standalone retail building had the highest total energy savings $(23 \%)$, while the warehouse had the least (3\%). Comparing between the two-stage and variable-speed compressor RTUs, there was an average of $1.5 \%$ extra total building energy savings. The use of SRM resulted in an average of $2.5 \%$ extra total building energy savings compared to the use of a VFD.

In addition to building energy savings, the upgrades also resulted in peak demand $(\mathrm{kW})$ reduction. A peak demand reduction as high as $11 \%$ was estimated for stand-alone retail buildings. In all building types, upgrading the RTU with the variable-speed compressor and SRM supply fan resulted in considerable peak kW savings. 


\section{Table of Contents}

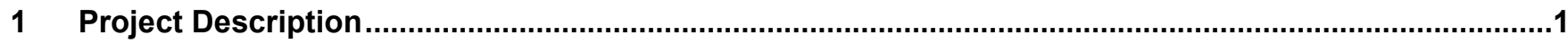

2 Definition of the Baseline RTU

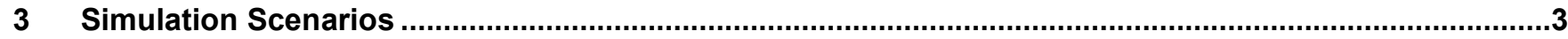

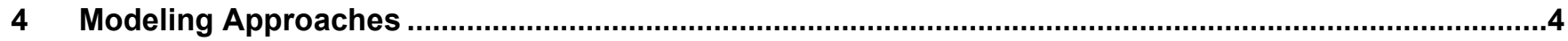

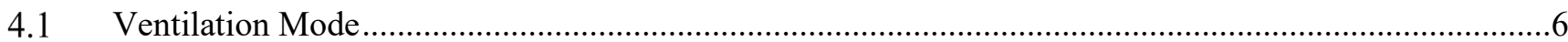

4.2 Cooling Mode

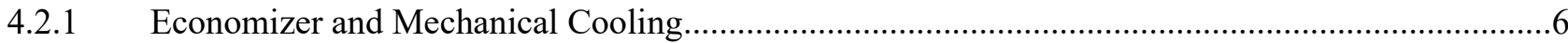

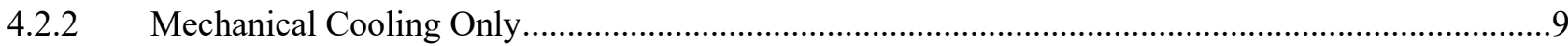

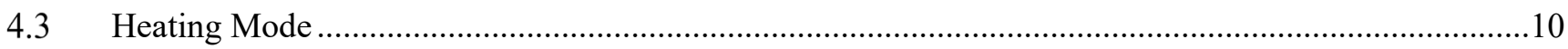

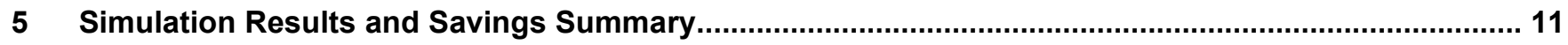

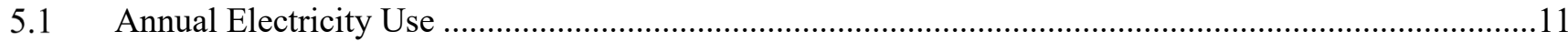

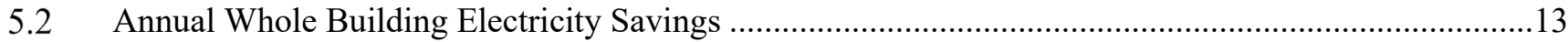

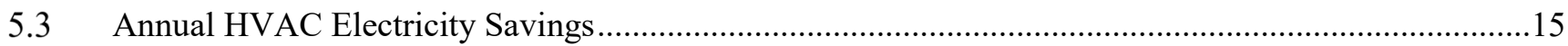

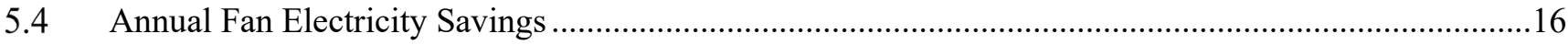

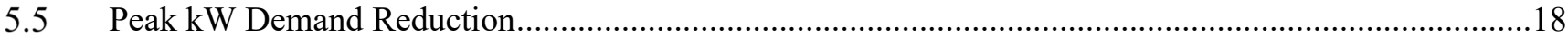

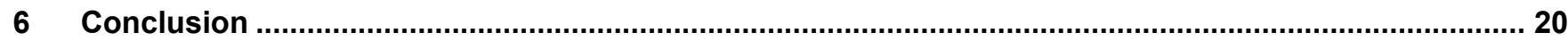

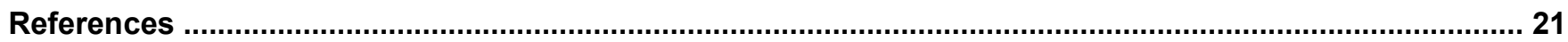

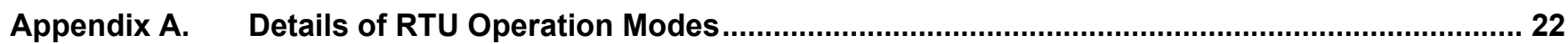




\section{List of Tables}

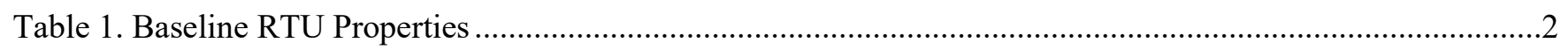

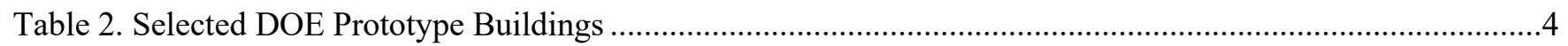

Table 3. Electricity Consumption Summary for Fast-Service Restaurant Building ..............................................11

Table 4. Electricity Consumption Summary for Full-Service Restaurant Building .............................................11

Table 5. Electricity Consumption Summary for Small Office Building ….......................................................12

Table 6. Electricity Consumption Summary for Stand-Alone Retail Building .................................................12

Table 7. Electricity Consumption Summary for Strip Mall Building …........................................................13

Table 8. Electricity Consumption Summary for Warehouse Building ..........................................................13

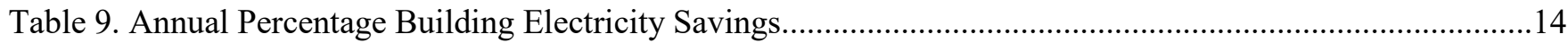

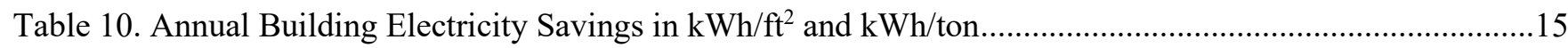

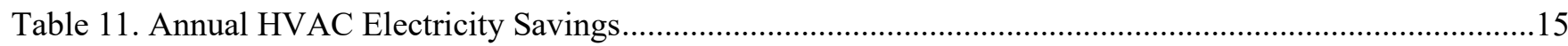

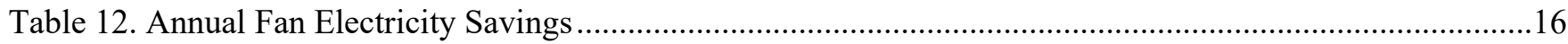

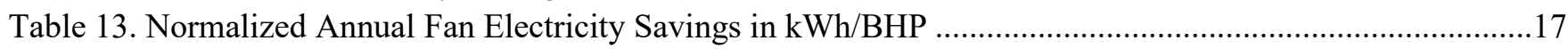

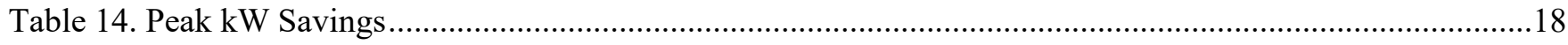

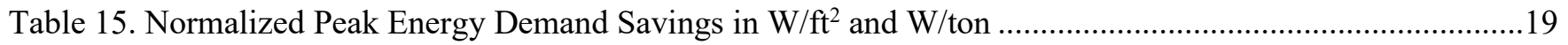

\section{List of Figures}

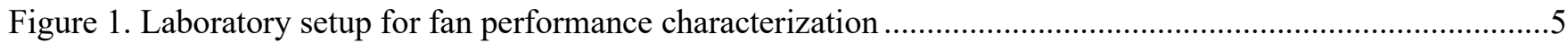

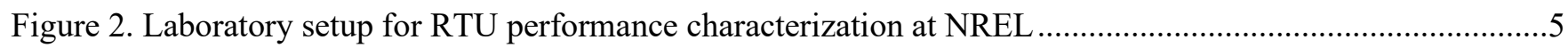

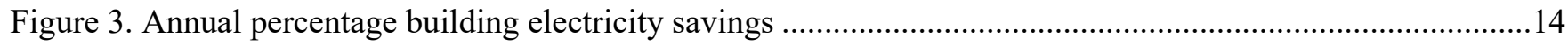

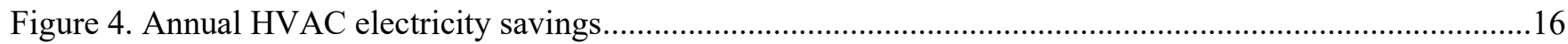

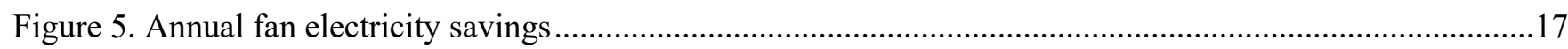

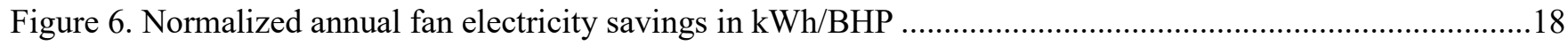

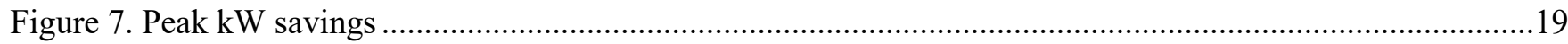

Figure A-1. Sequence of operations for baseline when outdoor air temperature is appropriate for economizer

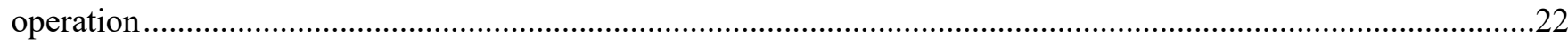

Figure A-2. Sequence of operations for baseline when outdoor air temperature is not appropriate for economizer

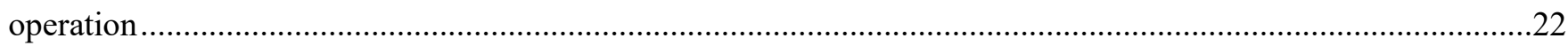

Figure A-3. Sequence of operations for Case 3 when outdoor air temperature is appropriate for economizer

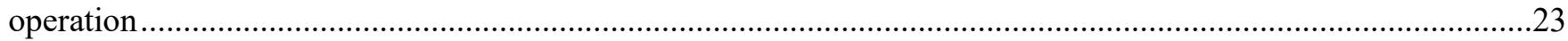

Figure A-4. Sequence of operations for Case 3 when outdoor air temperature is not appropriate for economizer

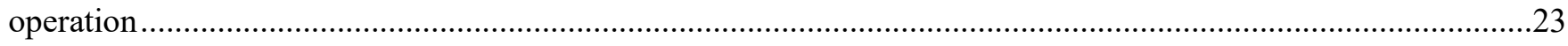

Figure A-5. Sequence of operations for Case 1 and Case 4 when outdoor air temperature is appropriate for

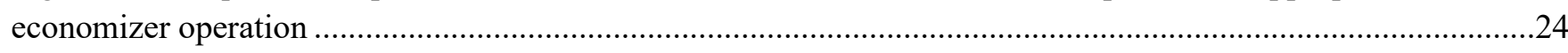

Figure A-6. Sequence of operations for Case 1 and Case 4 when outdoor air temperature is not appropriate for

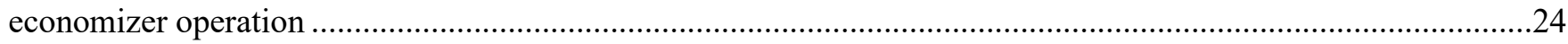

Figure A-7. Sequence of operations for Case 2 and Case 5 when outdoor air temperature is appropriate for

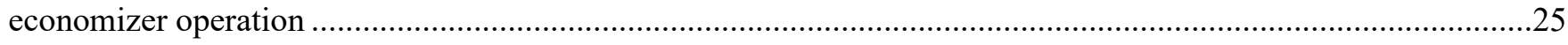

Figure A-8. Sequence of operations for Case 2 and Case 5 when outdoor air temperature is not appropriate for economizer operation 


\section{Project Description}

This project was part of an effort by ComEd to evaluate the energy saving potential of emerging technologies related to rooftop units (RTUs) in the Chicago area.

An RTU with a single-stage compressor and a constant-speed supply fan with an induction motor was selected as a baseline for the technology comparison. Three retrofit strategies were investigated. The first two involved replacing the single-stage compressor of the RTU with either a two-stage or variablespeed compressor and adding a variable frequency drive (VFD) to the constant speed fan. The use of a multi-/variable-stage compressor improves the part-load efficiency of the compressor, which will ultimately result in annual energy savings, as well as peak demand shaving in some cases where the design capacity of the RTU is larger than the maximum cooling load of the building space that it is serving. The third technology investigated was the use of a high rotor pole switched reluctance motor (SRM) as a replacement for the constant-speed supply fan. The SRM was applied in single-speed, twostage, and variable-speed compressor RTUs. SRM motors run via reluctance torque. Their stator poles are driven by direct current (DC) power and require an inverter as well as active control when using alternating current power. This inherent property results in high efficiency over a range of operating conditions. It also exhibits higher efficiency compared to VFDs since its switching frequency is much slower (Southern California Edison [SCE] 2018).

The three technologies investigated are summarized below:

- Replacing the single-speed compressor with a two-stage compressor and adding a VFD to the supply fan

- Replacing the single-speed compressor with a variable-speed compressor and adding a VFD to the supply fan

- Replacing the constant-speed induction motor of the supply fan with a high rotor pole SRM.

The U.S. Department of Energy's (DOE's) building simulation platform EnergyPlus

(https://energyplus.net) and its graphical user interface OpenStudio ${ }^{\circledR}$ (https://www.openstudio.net) were used to evaluate the energy-saving potential of upgrading RTUs by leveraging experimental data from previous research. 


\section{Definition of the Baseline RTU}

A new 10-ton RTU with a single-stage compressor for cooling, a gas furnace for heating, and a constantspeed induction motor supply fan was selected as the baseline RTU. Its rated performance was based on ASHRAE's latest performance requirement (ANSI/ASHRAE/IES-90.1-2016). For a 10-ton packaged RTU with gas heat, ASHRAE 90.1-2016 requires an integrated energy efficiency ratio (IEER) of at least 12.7. EnergyPlus uses a series of performance curves normalized to a rated coefficient of performance when representing the air conditioning portion of the RTU - the compressor and condenser fan - but ASHRAE only specifies IEER, which is composed of weighted performance at a variety of loading conditions (DOE 2018). To find the rated coefficient of performance, the RTU model was simulated for various coefficients of performance values, and the one that resulted in the specified IEER was picked. The supply air fan efficiency was assumed to be $25 \%$ at a fan pressure rise of $440 \mathrm{~Pa}$ (SCE 2018).

Part-load performance characteristics of the baseline RTU were assumed to be similar to the part-load performance characteristics of the second-stage compressor of the two-stage RTU used in this study. Further detail is provided in Section 4. Assumptions regarding economizer type and heating efficiency were taken from previous research done at the National Renewable Energy Laboratory (NREL) (Studer et al. 2012).

The performance properties of the baseline RTU are summarized in Table 1.

Table 1. Baseline RTU Properties

\begin{tabular}{ll}
\hline IEER & 12.7 \\
\hline Coefficient of Performance & 4.1 \\
\hline Fan Pressure Rise $(\mathrm{psi})$ & 0.064 \\
\hline Fan Mechanical Efficiency (\%) & 25 \\
\hline Fan Motor Type & Induction \\
\hline Heating Source & Gas \\
\hline Heating Efficiency & $80 \%$ \\
\hline Economizer Control & Fixed Dry Bulb Temperature \\
\hline Economizer Lock Point Temperature $\left({ }^{\circ} \mathrm{F}\right)$ & 65 \\
\hline Integrated Economizer and Mechanical Cooling Allowed? & Yes \\
\hline
\end{tabular}




\section{Simulation Scenarios}

Six different simulation scenarios were considered to evaluate the effect of the three technologies in different combinations:

- Baseline: Single-Stage Compressor and Constant-Speed Induction Motor Supply Fan

- Case 1: Two-Stage Compressor and Variable-Speed Induction Motor Supply Fan

- Case 2: Variable-Speed Compressor and Variable-Speed Induction Motor Supply Fan

- Case 3: Single-Stage Compressor and Variable-Speed SRM Supply Fan

- Case 4: Two-Stage Compressor and Variable-Speed SRM Supply Fan

- Case 5: Variable-Speed Compressor and Variable-Speed SRM Supply Fan. 


\section{Modeling Approaches}

Six different building types were selected by ComEd for this study. OpenStudio measures were used to generate ASHRAE 90.1-2013 code-compliant DOE prototype baseline models for each building type. The total conditioned area, the number of conditioned zones, and the peak cooling demand for each building are summarized in Table 2 .

Table 2. Selected DOE Prototype Buildings

\begin{tabular}{|c|c|c|c|c|c|c|}
\hline Building Type & $\begin{array}{l}\text { Small } \\
\text { Office }\end{array}$ & $\begin{array}{l}\text { Stand- } \\
\text { Alone } \\
\text { Retail }\end{array}$ & Warehouse & Strip Mall & $\begin{array}{l}\text { Fast-Service } \\
\text { Restaurant }\end{array}$ & $\begin{array}{l}\text { Full-Service } \\
\text { Restaurant }\end{array}$ \\
\hline $\begin{array}{l}\text { Conditioned Area } \\
\left(\mathrm{ft}^{2}\right)\end{array}$ & 5,502 & 24,692 & 52,045 & 22,500 & 2,501 & 5,502 \\
\hline $\begin{array}{l}\text { Number of } \\
\text { Conditioned } \\
\text { Zones }\end{array}$ & 5 & 4 & 3 & 10 & 2 & 2 \\
\hline $\begin{array}{l}\text { Total Fan Brake } \\
\text { Horsepower } \\
\text { (BHP) }\end{array}$ & 3.5 & 25 & 5 & 23 & 7 & 11 \\
\hline $\begin{array}{l}\text { Design Cooling } \\
\text { Load (Ton) }\end{array}$ & 8.5 & 65 & 13 & 69 & 20 & 33 \\
\hline
\end{tabular}

To evaluate the energy-saving potential of each technology, the baseline prototype models were modified using OpenStudio measures. OpenStudio measures are software scripts that can make changes to an OpenStudio building energy model. Three major updates were made to the prototype building models:

1. Replacing the existing constant-speed fans with SRM variable-speed fans or VFD fans and updating their performance curves

2. Replacing the existing single-speed RTUs with two-stage/variable-speed RTUs and updating their performance curves

3. Updating the control strategies based on the modes of operation.

EnergyPlus requires five performance curves for an air conditioning unit and one performance curve for a variable-speed fan to evaluate their energy consumption at different working conditions (DOE 2018). Data from prior research, discussed below, were used to generate these performance curves.

Prior experimental data from SCE's Emerging Products group was used to populate performance curves for induction and SRM supply fans. The SCE Emerging Products group collected the data by running the RTU's supply fan (fan/motor/drive) over three fixed-resistance conditions in inch of water column (WC) (0.4" WC, 1 " WC, and 1.5" WC) at seven different fan speeds in a controlled laboratory environment. The lab setup is shown in Figure 1.

Performance data collected in a test facility at NREL were used for the two-stage and variable-speed RTUs (Wheeler, Kozubal, and Judkoff 2018). The performance data were collected by running the RTU 
at different combinations of air flow, outdoor dry bulb temperature, and inlet air dry/wet-bulb temperature combinations. The temperature and flow ranges were selected to cover the full spectrum of the RTU's operating range. For the variable-speed RTU, the performance data were collected at four distinct compressor speeds $(25 \%, 50 \%, 75 \%$, and $100 \%)$ to characterize its performance at different compressor speeds. EnergyPlus treats variable-speed compressors as a multi-staged compressor and captures the overall performance by assigning a set of performance curves corresponding to each stage.

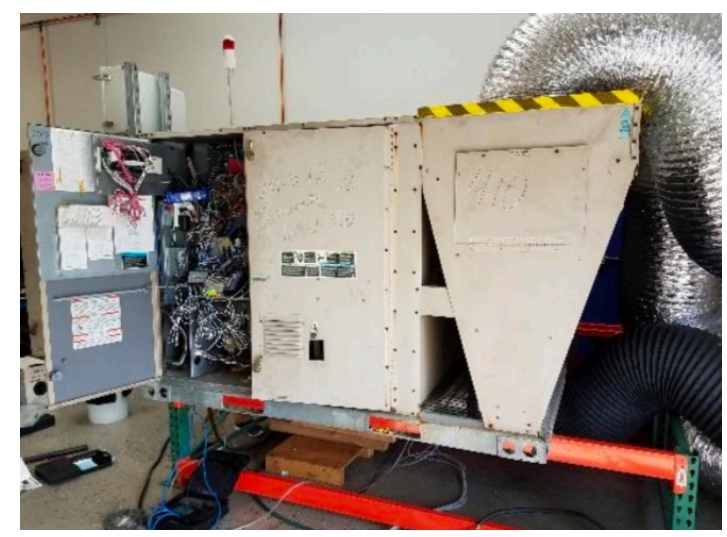

Figure 1. Laboratory setup for fan performance characterization Image credit: SCE

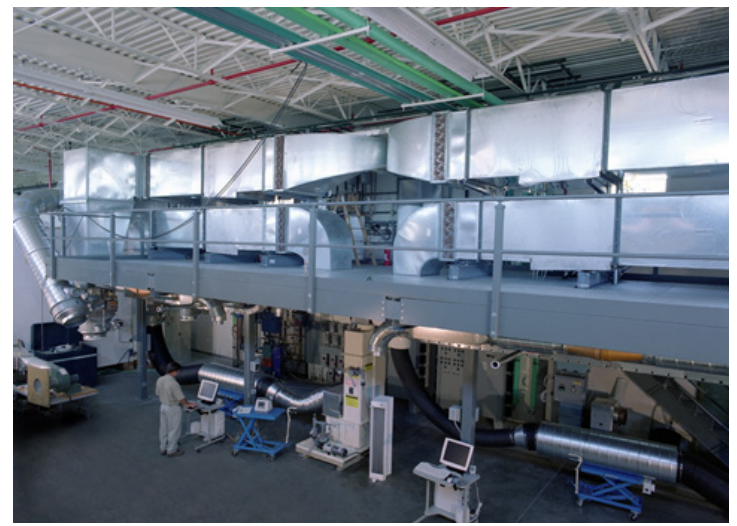

Figure 2. Laboratory setup for RTU performance characterization at NREL

Apart from the RTU's designed performance conditions, the way it is controlled plays a large role in its overall energy consumption. In this study, a custom EnergyPlus measure was applied to control the fan and the AC unit's operation. Based on the space and outdoor air conditions, the RTU was programmed to run in three different modes: ventilation mode, cooling mode, and heating mode. The summary of the control logic used for each technology is given in the sections below (4.1 to 4.5). Graphical representations of each mode of operation for each simulated case are shown in Appendix A. 


\subsection{Ventilation Mode}

Ventilation mode was activated when the space temperature was lower than the cooling setpoint and greater than the heating setpoint. During this mode, the following control strategies were used for each technology:

Single-Stage Compressor and Constant-Speed Fan (Baseline)

- The cooling and heating coils were turned off

- The outdoor air flow rate was set to the minimum ventilation air flow rate

- The supply air flow rate was set to the design value (constant-speed supply fan).

Single-Stage Compressor and Variable-Speed Fan (Case 3)

- The cooling and heating coils were turned off

- The outdoor air flow rate was set to the minimum ventilation air flow rate

- The supply air flow rate was set to the minimum ventilation air flow rate. Note that the minimum ventilation rate is building/zone dependent and different buildings/zones can have different minimum ventilation air flow rates.

Two-Stage Compressor and Variable-Speed Fan (Case 1, Case 4)

- The cooling and heating coils were turned off

- The outdoor air flow rate was set to the minimum ventilation air flow rate

- The supply air flow rate was set to the minimum ventilation air flow rate.

Variable-Speed Compressor and Variable-Speed Fan (Case 2, Case 5)

- The cooling and heating coils were turned off

- The outdoor air flow rate was set to the minimum ventilation air flow rate

- The supply air flow rate was set to the minimum ventilation air flow rate.

\subsection{Cooling Mode}

Cooling mode was activated when the space temperature was greater than the cooling setpoint. In cooling mode, the RTU was allowed to run in one of the two different modes: Economizer and Mechanical Cooling or Mechanical Cooling Only. To avoid cooling coil freezing, whenever mechanical cooling was activated, the minimum supply fan speed was limited to $60 \%$ for two-stage RTU (Case 1 and Case 4) and 40\% for variable-speed RTU (Case 2 and Case 5).

\subsubsection{Economizer and Mechanical Cooling}

Economizer and Mechanical Cooling was activated when the space temperature was greater than the cooling setpoint and the outdoor air temperature was appropriate for economizing (outdoor air temperature between $55^{\circ} \mathrm{F}$ and $65^{\circ} \mathrm{F}$ ). A value of $65^{\circ} \mathrm{F}$ was used as a lock point temperature for economizer operation instead of the ASHRAE Standard 90.1-recommended value of $70^{\circ} \mathrm{F}$ for climate 
zone 5A (Chicago area) to reflect what is most practical in the field. During this mode, the following control strategies were used for each technology:

Single-Stage Compressor and Constant-Speed Fan (Baseline)

- The outdoor air flow rate/outdoor air damper was allowed to modulate from its minimum to maximum values proportional to the difference between the space temperature and the cooling setpoint

- If the outdoor air flow rate was at maximum and the conditioned space needed more cooling (if cooling setpoint was not met), the cooling coil (compressor) was activated

- The RTU remained in this mode until the space temperature was lower than the cooling setpoint by $0.5^{\circ} \mathrm{F}$, at which point ventilation mode was activated.

Single-Stage Compressor and Variable-Speed Fan (Case 3)

- The supply air flow rate was allowed to modulate from minimum to maximum supply fan capacity proportional to the difference between the space temperature and the cooling setpoint. Every minute, for each $1{ }^{\circ} \mathrm{F}$ of difference between the space temperature and the cooling setpoint, the fan speed was allowed to increase by $5 \%$.

- The outdoor air flow rate was set to be equal to the supply air flow rate (the outdoor air damper was set to fully open)

- If the RTU air flow rate was at its maximum and the conditioned space needed more cooling, the cooling coil (compressor) was activated

- The RTU remained in this mode until the space temperature was lower than the cooling setpoint by $0.5^{\circ} \mathrm{F}$, at which point ventilation mode was activated.

Two-Stage Compressor and Variable-Speed Fan (Case 1, Case 4)

- The supply air flow rate was allowed to modulate from minimum to maximum supply fan capacity proportional to the difference between the space temperature and the cooling setpoint. Every minute, for each $1^{\circ} \mathrm{F}$ of difference between the space temperature and the cooling setpoint, the fan speed was allowed to increase by $5 \%$.

- The outdoor air flow rate was set to be equal to the supply air flow rate (the outdoor air damper was set to fully open)

- If the supply flow rate was at its maximum capacity and the conditioned space needed more cooling:

- The first-stage cooling was activated, and the supply fan was set to the first-stage maximum air flow rate until the space temperature fell below the cooling setpoint by $0.5^{\circ} \mathrm{F}$, at which point ventilation mode was activated

- If the space temperature was greater than the cooling setpoint by $0.5^{\circ} \mathrm{F}$, second-stage cooling was activated

- In second-stage cooling, the RTU air flow rate was allowed to modulate from the first-stage maximum to second-stage maximum air flow rate in proportion to the difference between the space temperature and the cooling setpoint. Every minute, for each $1^{\circ} \mathrm{F}$ of difference between the space temperature and the cooling setpoint, the fan speed was allowed to increase by $5 \%$. 
- The RTU remained in second-stage cooling until the space temperature fell below the cooling setpoint by $0.25^{\circ} \mathrm{F}$, at which point the second-stage cooling was set to off.

- The RTU remained in this mode until the space temperature was lower than the cooling setpoint by $0.5^{\circ} \mathrm{F}$, at which point ventilation mode was activated.

Variable-Speed Compressor and Variable-Speed Fan (Case 2, Case 5)

- The outdoor air damper was set to fully open

- The supply air flow rate was allowed to modulate from minimum to maximum supply fan capacity proportional to the difference between the space temperature and the cooling setpoint

- If the supply fan flow rate was at maximum and the conditioned space called for more cooling:

- First-stage cooling was activated, and the supply fan flow rate was set to the first-stage maximum air flow rate

- After the first-stage cooling was activated, if the space temperature fell below the cooling setpoint by $0.5^{\circ} \mathrm{F}$, ventilation mode was activated

- After first-stage cooling was activated, if the space temperature was greater than the cooling setpoint by $0.15^{\circ} \mathrm{F}$, second-stage cooling was activated

O In second-stage cooling, the RTU air flow rate was allowed to modulate from the first-stage maximum to second-stage maximum air flow rate in proportion to the difference between the space temperature and the cooling setpoint

- The RTU remained in second-stage cooling until the space temperature fell below the cooling setpoint by $0.25^{\circ} \mathrm{F}$, at which point the unit was set to first-stage cooling

- After the second-stage cooling was activated, if the space temperature was greater than the cooling setpoint by $0.35^{\circ} \mathrm{F}$, third-stage cooling was activated

- In third-stage cooling, the RTU air flow rate was allowed to modulate from the second-stage maximum to third-stage maximum air flow rate in proportion to the difference between the space temperature and the cooling setpoint

- The RTU remained in third-stage cooling until the space temperature fell below the cooling setpoint by $0.25^{\circ} \mathrm{F}$, at which point the unit was set to first-stage cooling

- After third-stage cooling was activated, if the space temperature was greater than the cooling setpoint by $0.5^{\circ} \mathrm{F}$, fourth-stage cooling was activated

- In fourth-stage cooling, the RTU air flow rate was allowed to modulate from the third-stage maximum to fourth-stage maximum air flow rate (design air flow rate) in proportion to the difference between the space temperature and the cooling setpoint

○ The RTU remained in fourth-stage cooling until the space temperature fell below the cooling setpoint by $0.25^{\circ} \mathrm{F}$, at which point the unit was set to first-stage cooling.

- The RTU remained in this mode until the space temperature was lower than the cooling setpoint by $0.5^{\circ} \mathrm{F}$, at which point the ventilation mode was activated. 


\subsubsection{Mechanical Cooling Only}

Mechanical cooling only was activated when the space temperature was greater than the cooling setpoint and outdoor air was not convenient for economizing (outdoor air temperature greater than $65^{\circ} \mathrm{F}$ ). During this mode, the following control strategies were used for each technology:

Single-Stage Compressor and Constant-Speed Fan (Baseline)

- The outdoor air flow rate was set to the minimum ventilation flow rate

- The cooling coil was activated

- The RTU remained in this mode until the space temperature was lower than the cooling setpoint by $0.5^{\circ} \mathrm{F}$, at which point the ventilation mode was activated.

Single-Stage Compressor and Variable-Speed Fan (Case 3)

- The outdoor air flow rate was set to the minimum ventilation flow rate

- The cooling coil was activated

- The supply fan flow rate was kept at the maximum flow rate

- The RTU remained in this mode until the space temperature was lower than the cooling setpoint by $0.5^{\circ} \mathrm{F}$, at which point the ventilation mode was activated.

Two-Stage Compressor and Variable-Speed Fan (Case 1, Case 4)

- The outdoor air flow rate was set to the minimum ventilation flow rate

- The first-stage compressor was activated

- The supply fan flow rate was allowed to modulate between the minimum and the first-stage maximum flow rate based on the difference between the space temperature and the cooling setpoint

- The RTU remained in first-stage cooling until the space temperature was lower than the cooling setpoint by $0.5^{\circ} \mathrm{F}$, at which point the ventilation mode was activated

- After the first-stage compressor was on, if the space temperature rose above the cooling setpoint by $0.5^{\circ} \mathrm{F}$, the second-stage compressor was engaged

- In second-stage cooling, the supply fan air flow rate was allowed to modulate between the first-stage maximum and second-stage maximum air flow rate based on the difference between the space temperature and the cooling setpoint

- The RTU remained in second-stage cooling until the space temperature was below the cooling setpoint by $0.25^{\circ} \mathrm{F}$, at which point the unit was set to first-stage cooling.

Variable-Speed Compressor and Variable-Speed Fan (Case 2, Case 5)

- The outdoor air flow rate was set to the minimum ventilation air flow rate

- The first-stage compressor was activated

- The supply fan flow rate was allowed to modulate between the minimum and the first-stage maximum flow rate based on the difference between the space temperature and the cooling setpoint

- The RTU remained in first-stage cooling until the space temperature was lower than the cooling setpoint by $0.5^{\circ} \mathrm{F}$, at which point ventilation mode was activated

- If the space temperature was greater than the cooling setpoint by $0.15^{\circ} \mathrm{F}$, the second-stage compressor was engaged 
- In second-stage cooling, the supply fan flow rate was allowed to modulate between the first-stage maximum and second-stage maximum air flow rate based on the difference between the space temperature and the cooling setpoint

- The RTU remained in second-stage cooling until the space temperature was below the cooling setpoint by $0.25^{\circ} \mathrm{F}$, at which point the unit was set to first-stage cooling

- If the space temperature was greater than the cooling setpoint by $0.35^{\circ} \mathrm{F}$, the third-stage compressor was engaged

- In the third-stage cooling, the supply fan flow rate was allowed to modulate between the secondstage maximum and third-stage maximum air flow rate based on the difference between the space temperature and the cooling setpoint

- The RTU remained in third-stage cooling until the space temperature was below the cooling setpoint by $0.25^{\circ} \mathrm{F}$, at which point the unit was set to first-stage cooling

- If the space temperature was greater than the cooling setpoint by $0.5^{\circ} \mathrm{F}$, the fourth-stage compressor was engaged

- In fourth-stage cooling, the RTU air flow rate was allowed to modulate between the third-stage maximum and fourth-stage maximum air flow rate based on the difference between the space temperature and the cooling setpoint

- The RTU remained in fourth-stage cooling until the space temperature was below the cooling setpoint by $0.25^{\circ} \mathrm{F}$, at which point the unit was set to first-stage cooling

- The RTU remained in mechanical cooling until the space temperature was below the cooling setpoint by $0.5^{\circ} \mathrm{F}$, at which point the ventilation mode was activated.

\subsection{Heating Mode}

Heating mode was activated when the space temperature was lower than the heating setpoint. All the technologies shared similar control logic during heating mode, summarized below:

- The outdoor air flow rate was set to minimum ventilation flow rate

- The supply fan flow rate was set to the maximum flow rate

- The heating coil was on

- The RTU remained in this mode until the space temperature was greater than the heating setpoint by $0.5^{\circ} \mathrm{F}$, at which point the ventilation mode was activated. 


\section{Simulation Results and Savings Summary}

A total of 36 simulations were performed (the baseline models plus five different retrofit options across six building types) using Typical Meteorological Year 3 weather data for Chicago. Key simulation results and findings are presented in the subsections below.

\subsection{Annual Electricity Use}

Table 3 through Table 8 show the summary of annual energy consumption as well as annual peak kW demand for each building type. Both gross and normalized (by conditioned area and tonnage) energy consumption and peak demand data are provided. The tables also provide energy consumption by end use (AC and supply fan).

Table 3. Electricity Consumption Summary for Fast-Service Restaurant Building

\begin{tabular}{lllllll}
\hline Fast-Service Restaurant & Baseline & Case 1 & Case 2 & Case 3 & Case 4 & Case 5 \\
\hline Total Building Annual kWh & 151,757 & 140,610 & 136,565 & 138,665 & 136,420 & 132,666 \\
\hline $\begin{array}{l}\text { Annual AC (Compressor + Condenser } \\
\text { Fan) kWh }\end{array}$ & 8,926 & 8,461 & 5,550 & 8,090 & 7,917 & 7,490 \\
\hline Annual Supply Fan kWh & 38,159 & 27,489 & 23,558 & 25,917 & 23,847 & 20,572 \\
\hline Peak Building kW & 38.0 & 38.0 & 36.1 & 36.9 & 37.1 & 35.4 \\
\hline Total Building Annual kWh/ft ${ }^{2}$ & 61 & 56 & 55 & 55 & 55 & 53 \\
\hline Total Building Annual kWh/ton & 7,588 & 7,031 & 6,828 & 6,933 & 6,821 & 6,633 \\
\hline (AC + Supply Fan) kWh/ft ${ }^{2}$ & 19 & 14 & 12 & 14 & 13 & 11 \\
\hline (AC + Supply Fan) kWh/ton & 2,354 & 1,798 & 1,455 & 1,700 & 1,588 & 1,403 \\
\hline Peak W/ft ${ }^{2}$ & 15.2 & 15.2 & 14.5 & 14.7 & 14.8 & 14.1 \\
\hline Peak KW/ton & 1.90 & 1.90 & 1.81 & 1.84 & 1.86 & 1.77 \\
\hline
\end{tabular}

Table 4. Electricity Consumption Summary for Full-Service Restaurant Building

\begin{tabular}{llllllc}
\hline Full-Service Restaurant & Baseline & Case 1 & Case 2 & Case 3 & Case 4 & Case 5 \\
\hline Total Building Annual kWh & 269,217 & 249,369 & 246,035 & 247,790 & 242,756 & 239,674 \\
\hline $\begin{array}{l}\text { Annual AC (Compressor + Condenser } \\
\text { Fan) kWh }\end{array}$ & 17,210 & 16,142 & 16,356 & 15,666 & 15,867 & 15,997 \\
\hline Annual Supply Fan kWh & 60,039 & 41,195 & 36,467 & 40,221 & 34,910 & 30,508 \\
\hline Peak Building kW & 65 & 65 & 61 & 63 & 64 & 60 \\
\hline Total Building Annual kWh/ft ${ }^{2}$ & 49 & 45 & 45 & 45 & 44 & 44 \\
\hline Total Building Annual kWh/ton & 8,158 & 7,557 & 7,456 & 7,509 & 7,356 & 7,263 \\
\hline (AC + Supply Fan) kWh/ft' & 14 & 10 & 10 & 10 & 9 & 8 \\
\hline (AC + Supply Fan) kWh/ton & 2,341 & 1,737 & 1,601 & 1,694 & 1,539 & 1,409 \\
\hline Peak W/ft & 11.8 & 11.8 & 11.2 & 11.5 & 11.6 & 10.9 \\
\hline Peak KW/ton & 1.97 & 1.97 & 1.86 & 1.92 & 1.93 & 1.82 \\
\hline
\end{tabular}


Table 5. Electricity Consumption Summary for Small Office Building

\begin{tabular}{lllllll}
\hline Small Office & Baseline & Case 1 & Case 2 & Case 3 & Case 4 & Case 5 \\
\hline Total Building Annual kWh & 49,233 & 44,626 & 44,477 & 45,311 & 43,679 & 43,516 \\
\hline $\begin{array}{l}\text { Annual AC (Compressor + Condenser Fan) } \\
\text { kWh }\end{array}$ & 3,706 & 3,766 & 3,558 & 3,355 & 3,719 & 3,493 \\
\hline Annual Supply Fan kWh & 8,946 & 4,582 & 4,642 & 5,374 & 3,681 & 3,745 \\
\hline Peak Building kW & 17 & 17 & 16 & 17 & 17 & 15 \\
\hline Total Building Annual kWh/ft ${ }^{2}$ & 8.9 & 8.1 & 8.1 & 8.2 & 7.9 & 7.9 \\
\hline Total Building Annual kWh/ton & 5,861 & 5,313 & 5,295 & 5,394 & 5,200 & 5,180 \\
\hline (AC + Supply Fan) kWh/ft ${ }^{2}$ & 2.30 & 1.52 & 1.49 & 1.59 & 1.35 & 1.32 \\
\hline (AC + Supply Fan) kWh/ton & 1,506 & 994 & 976 & 1,039 & 881 & 862 \\
\hline Peak W/ft ${ }^{2}$ & 3.1 & 3.1 & 2.9 & 3.1 & 3.0 & 2.8 \\
\hline Peak KW/ton & 2.03 & 2.02 & 1.88 & 2.01 & 1.99 & 1.83 \\
\hline
\end{tabular}

Table 6. Electricity Consumption Summary for Stand-Alone Retail Building

\begin{tabular}{lllllll}
\hline Retail Stand-Alone & Baseline & Case 1 & Case 2 & Case 3 & Case 4 & Case 5 \\
\hline Total Building Annual kWh & 321,677 & 257,243 & 256,706 & 270,515 & 248,947 & 248,230 \\
\hline $\begin{array}{l}\text { Annual AC (Compressor + Condenser } \\
\text { Fan) kWh }\end{array}$ & 33,722 & 29,110 & 29,316 & 29,832 & 28,596 & 28,614 \\
\hline Annual Supply Fan kWh & 103,744 & 43,713 & 43,621 & 55,876 & 35,929 & 35,890 \\
\hline Peak Building kW & 98 & 96 & 89 & 94 & 93 & 87 \\
\hline Total Building Annual kWh/ft ${ }^{2}$ & 13 & 10 & 10 & 11 & 10 & 10 \\
\hline Total Building Annual kWh/ton & 4,949 & 3,958 & 3,949 & 4,162 & 3,830 & 3,819 \\
\hline (AC + Supply Fan) kWh/ft & 5.6 & 2.9 & 3.0 & 3.5 & 2.6 & 2.6 \\
\hline (AC + Supply Fan) kWh/ton & 2,115 & 1,120 & 1,122 & 1,319 & 993 & 992 \\
\hline Peak W/ft & 4.0 & 3.9 & 3.6 & 3.8 & 3.8 & 3.5 \\
\hline Peak KW/ton & 1.5 & 1.5 & 1.4 & 1.4 & 1.4 & 1.3 \\
\hline
\end{tabular}


Table 7. Electricity Consumption Summary for Strip Mall Building

\begin{tabular}{lllllll}
\hline Strip Mall & Baseline & Case 1 & Case 2 & Case 3 & Case 4 & Case 5 \\
\hline Total Building Annual kWh & 350,318 & 295,878 & 292,421 & 302,649 & 285,632 & 281,631 \\
\hline $\begin{array}{l}\text { Annual AC (Compressor + Condenser } \\
\text { Fan) kWh }\end{array}$ & 31,094 & 27,738 & 27,629 & 28,917 & 27,388 & 27,780 \\
\hline Annual Supply Fan kWh & 105,100 & 54,006 & 50,660 & 59,596 & 44,109 & 39,736 \\
\hline Peak Building kW & 114 & 112 & 106 & 114 & 109 & 104 \\
\hline Total Building Annual kWh/ft ${ }^{2}$ & 15.6 & 13.2 & 13.0 & 13.5 & 12.7 & 12.5 \\
\hline Total Building Annual kWh/ton & 5,077 & 4,288 & 4,238 & 4,386 & 4,140 & 4,082 \\
\hline (AC + Supply Fan) kWh/ft ${ }^{2}$ & 6.1 & 3.6 & 3.5 & 3.9 & 3.2 & 3.0 \\
\hline (AC + Supply Fan) kWh/ton & 1,974 & 1,185 & 1,135 & 1,283 & 1,036 & 978 \\
\hline Peak W/ft ${ }^{2}$ & 5.1 & 5.0 & 4.7 & 5.1 & 4.9 & 4.6 \\
\hline Peak KW/ton & 1.65 & 1.62 & 1.54 & 1.65 & 1.59 & 1.51 \\
\hline
\end{tabular}

Table 8. Electricity Consumption Summary for Warehouse Building

\begin{tabular}{lllllll}
\hline Warehouse & Baseline & Case 1 & Case 2 & Case 3 & Case 4 & Case 5 \\
\hline Total Building Annual kWh & 181,139 & 176,205 & 176,402 & 174,407 & 173,848 & 174,009 \\
\hline $\begin{array}{l}\text { Annual AC (Compressor + Condenser } \\
\text { Fan) kWh }\end{array}$ & 1,666 & 1,648 & 1,698 & 1,483 & 1,624 & 1,664 \\
\hline Annual Supply Fan kWh & 19,327 & 14,409 & 14,557 & 12,777 & 12,077 & 12,198 \\
\hline Peak Building kW & 47 & 47 & 47 & 46 & 46 & 46 \\
\hline Total Building Annual kWh/ft ${ }^{2}$ & 3.5 & 3.4 & 3.4 & 3.4 & 3.3 & 3.3 \\
\hline Total Building Annual kWh/ton & 13,934 & 13,554 & 13,569 & 13,416 & 13,373 & 13,385 \\
\hline (AC + Supply Fan) kWh/ft & 0.40 & 0.31 & 0.31 & 0.27 & 0.26 & 0.27 \\
\hline (AC + Supply Fan) kWh/ton & 1,615 & 1,235 & 1,250 & 1,097 & 1,054 & 1,066 \\
\hline Peak W/ft & 0.90 & 0.90 & 0.90 & 0.89 & 0.89 & 0.89 \\
\hline Peak KW/ton & 3.60 & 3.60 & 3.60 & 3.56 & 3.56 & 3.56 \\
\hline
\end{tabular}

\subsection{Annual Whole Building Electricity Savings}

Table 9 and Figure 3 show annual energy savings in percentages corresponding to each building type. Based on the simulation results, all upgrade types (Case 1 to Case 5) are predicted to result in energy savings ranging from 3\%-23\% compared to the baseline energy consumption. The stand-alone retail building type is observed to benefit the most from the upgrades, while the warehouse building type exhibited the least savings, due to the relative contribution of heating, ventilating, and air conditioning (HVAC) to overall energy consumption in each building type: only $11 \%$ for the warehouse building, in contrast to $42 \%$ for the stand-alone retail building. Enhanced part-load efficiencies from twostage/variable-speed compressor and variable-speed supply fans contributed to the annual energy savings. Of all the retrofit types, Case 5 showed the highest savings for most of the building types. The 
normalized energy savings in $\mathrm{kWh} /$ ton and $\mathrm{kWh} / \mathrm{ft}^{2}$ compared to the baseline are shown in Table 10 . The savings ranged from $0.1-7.6 \mathrm{kWh} / \mathrm{ft}^{2}$ and from $364-1,146 \mathrm{kWh} / \mathrm{ton}$.

Table 9. Annual Percentage Building Electricity Savings

\begin{tabular}{lllllll}
\hline Case Type & $\begin{array}{l}\text { Fast-Service } \\
\text { Restaurant }\end{array}$ & $\begin{array}{l}\text { Full-Service } \\
\text { Restaurant }\end{array}$ & $\begin{array}{l}\text { Small } \\
\text { Office }\end{array}$ & $\begin{array}{l}\text { Stand-Alone } \\
\text { Retail }\end{array}$ & Strip Mall & Warehouse \\
\hline Case $\mathbf{1}$ & $7 \%$ & $7 \%$ & $9 \%$ & $20 \%$ & $16 \%$ & $3 \%$ \\
\hline Case 2 & $10 \%$ & $9 \%$ & $10 \%$ & $20 \%$ & $17 \%$ & $3 \%$ \\
\hline Case 3 & $9 \%$ & $8 \%$ & $8 \%$ & $16 \%$ & $14 \%$ & $4 \%$ \\
\hline Case 4 & $10 \%$ & $10 \%$ & $11 \%$ & $23 \%$ & $18 \%$ & $4 \%$ \\
\hline Case 5 & $13 \%$ & $11 \%$ & $12 \%$ & $23 \%$ & $20 \%$ & $4 \%$ \\
\hline
\end{tabular}

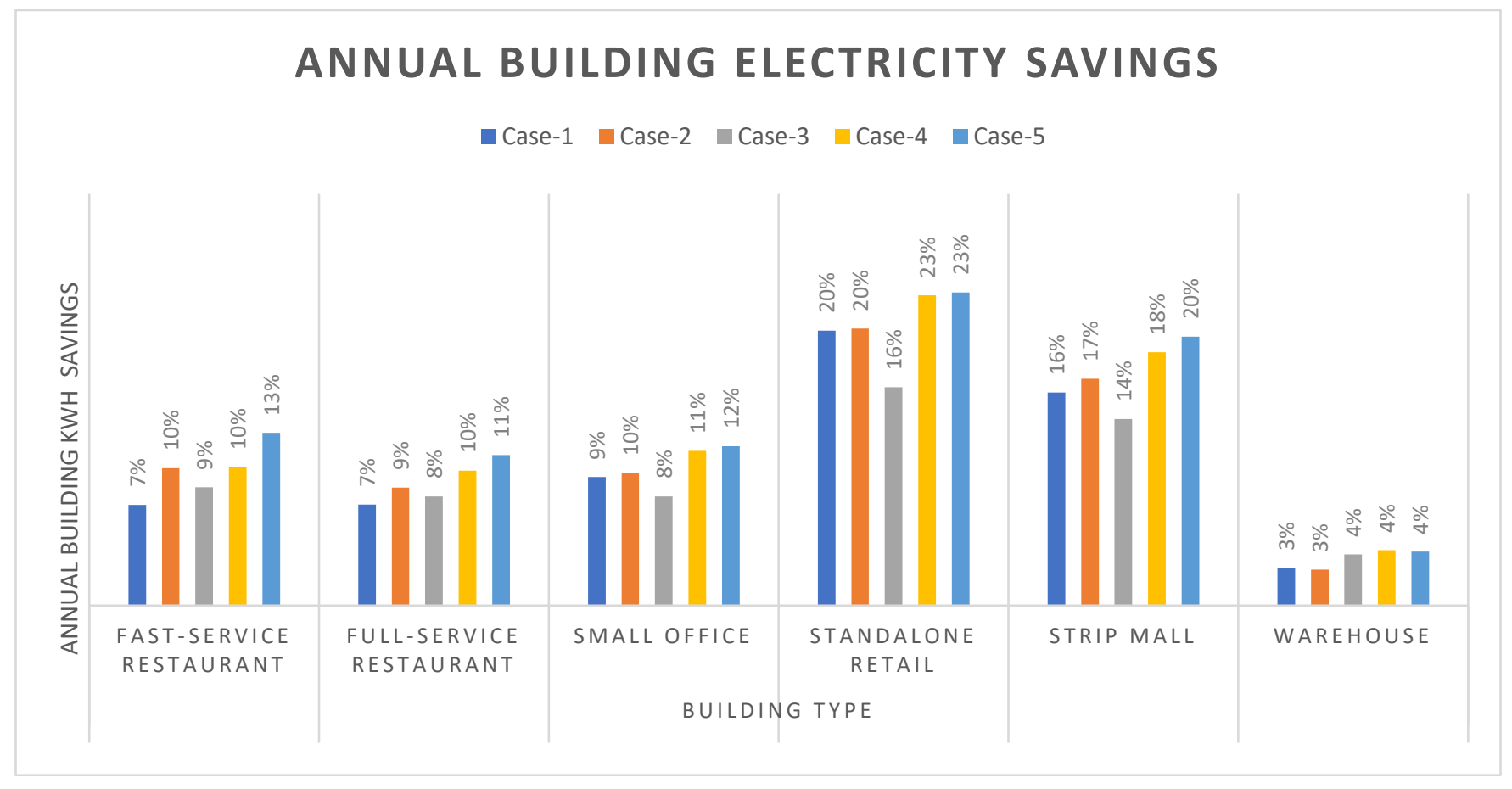

Figure 3. Annual percentage building electricity savings 
Table 10. Annual Building Electricity Savings in $\mathrm{kWh} / \mathrm{ft}^{2}$ and $\mathrm{kWh} / \mathrm{ton}$

\begin{tabular}{|c|c|c|c|c|c|c|}
\hline & & Case 1 & Case 2 & Case 3 & Case 4 & Case 5 \\
\hline \multirow{2}{*}{$\begin{array}{l}\text { Fast- } \\
\text { Service } \\
\text { Restaurant }\end{array}$} & $\left(\mathrm{kWh} / \mathrm{ft}^{2}\right)$ & 4.5 & 6.1 & 5.2 & 6.1 & 7.6 \\
\hline & (kWh/Ton) & 557.3 & 759.6 & 654.6 & 766.8 & 954.6 \\
\hline \multirow{2}{*}{$\begin{array}{l}\text { Full- } \\
\text { Service } \\
\text { Restaurant }\end{array}$} & $\left(\mathrm{kWh} / \mathrm{ft}^{2}\right)$ & 3.6 & 4.2 & 3.9 & 4.8 & 5.4 \\
\hline & (kWh/Ton) & 601.4 & 702.5 & 649.3 & 801.8 & 895.2 \\
\hline \multirow{2}{*}{$\begin{array}{l}\text { Small } \\
\text { Office }\end{array}$} & $\left(\mathrm{kWh} / \mathrm{ft}^{2}\right)$ & 0.8 & 0.9 & 0.7 & 1.0 & 1.0 \\
\hline & (kWh/Ton) & 548.5 & 566.2 & 466.9 & 661.2 & 680.6 \\
\hline \multirow{2}{*}{$\begin{array}{l}\text { Stand- } \\
\text { Alone } \\
\text { Retail }\end{array}$} & $\left(\mathrm{kWh} / \mathrm{ft}^{2}\right)$ & 2.6 & 2.7 & 2.1 & 2.9 & 3.0 \\
\hline & (kWh/Ton) & 989.9 & $1,026.6$ & 787.1 & $1,120.3$ & $1,146.9$ \\
\hline \multirow[t]{2}{*}{ Strip Mall } & $\left(\mathrm{kWh} / \mathrm{ft}^{2}\right)$ & 2.4 & 2.6 & 2.1 & 2.9 & 3.1 \\
\hline & (kWh/Ton) & 789.0 & 839.1 & 690.9 & 937.5 & 995.5 \\
\hline \multirow[t]{2}{*}{ Warehouse } & $\left(\mathrm{kWh} / \mathrm{ft}^{2}\right)$ & 0.1 & 0.1 & 0.1 & 0.1 & 0.1 \\
\hline & (kWh/Ton) & 379.6 & 364.4 & 517.9 & 560.9 & 548.5 \\
\hline
\end{tabular}

\subsection{Annual HVAC Electricity Savings}

Considering only HVAC systems (AC and supply fan), annual electricity savings ranging from $23 \%-$ 53\% were predicted (Table 11 and Figure 4). Stand-alone retail and warehouse building types exhibited the highest and lowest annual HVAC energy savings, respectively. As the electricity savings in the building comes from upgrading the supply fan and compressor types, the normalized HVAC energy savings in $\mathrm{kWh} / \mathrm{ft}^{2}$ and $\mathrm{kWh} /$ ton were similar to the building level savings as indicated in Table 10.

Table 11. Annual HVAC Electricity Savings

\begin{tabular}{lllllll}
\hline Case Type & $\begin{array}{l}\text { Fast-Service } \\
\text { Restaurant }\end{array}$ & $\begin{array}{l}\text { Full-Service } \\
\text { Restaurant }\end{array}$ & $\begin{array}{l}\text { Small } \\
\text { Office }\end{array}$ & $\begin{array}{l}\text { Stand-Alone } \\
\text { Retail }\end{array}$ & Strip Mall & Warehouse \\
\hline Case 1 & $24 \%$ & $26 \%$ & $34 \%$ & $47 \%$ & $40 \%$ & $24 \%$ \\
\hline Case 2 & $38 \%$ & $32 \%$ & $35 \%$ & $47 \%$ & $43 \%$ & $23 \%$ \\
\hline Case 3 & $28 \%$ & $28 \%$ & $31 \%$ & $38 \%$ & $35 \%$ & $32 \%$ \\
\hline Case 4 & $33 \%$ & $34 \%$ & $42 \%$ & $53 \%$ & $48 \%$ & $35 \%$ \\
\hline Case 5 & $40 \%$ & $40 \%$ & $43 \%$ & $53 \%$ & $50 \%$ & $34 \%$ \\
\hline
\end{tabular}




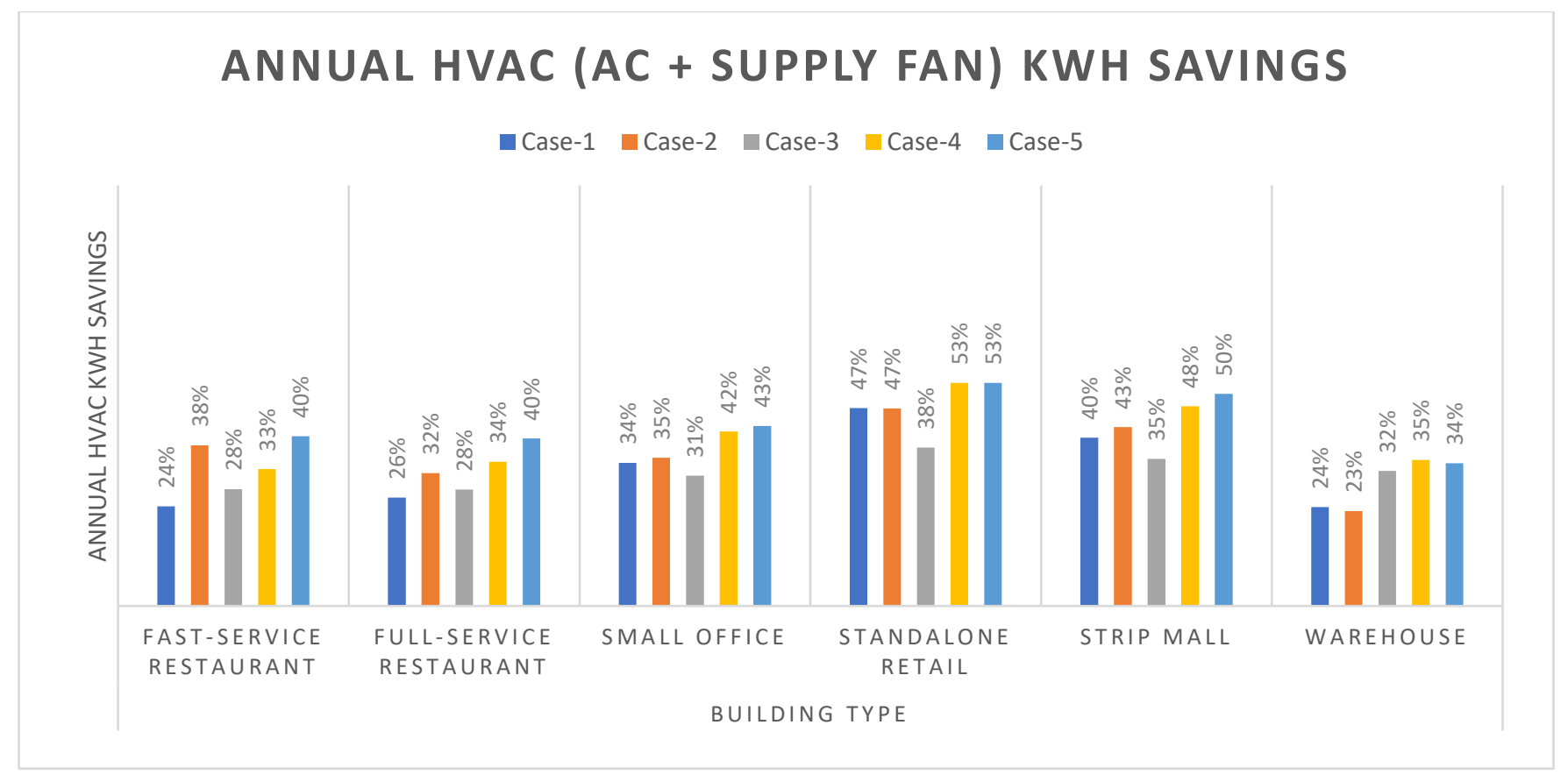

Figure 4. Annual HVAC electricity savings

\subsection{Annual Fan Electricity Savings}

Table 12 and Figure 5 show the predicted annual fan energy savings for each upgrade type compared to the baseline constant-speed fan energy consumption. Energy savings ranging from $25 \%-65 \%$ were predicted. Use of the SRM supply fan for two-stage/variable-speed compressor RTUs (Case 4 and Case 5 ) is also predicted to result in around 9\% extra fan energy savings on average compared to conventional supply fan with variable frequency drive induction motors (Case 1). Normalized annual supply fan energy savings in $\mathrm{kWh} / \mathrm{BHP}$ are shown in Table 13 and Figure 6. Savings ranging from $954 \mathrm{kWh} / \mathrm{BHP}-$ $2,842 \mathrm{kWh} / \mathrm{BHP}$ were predicted.

Table 12. Annual Fan Electricity Savings

\begin{tabular}{lllllll}
\hline $\begin{array}{l}\text { Case } \\
\text { Type }\end{array}$ & $\begin{array}{l}\text { Fast-Service } \\
\text { Restaurant }\end{array}$ & $\begin{array}{l}\text { Full-Service } \\
\text { Restaurant }\end{array}$ & $\begin{array}{l}\text { Small } \\
\text { Office }\end{array}$ & $\begin{array}{l}\text { Stand-Alone } \\
\text { Retail }\end{array}$ & Strip Mall & Warehouse \\
\hline Case 1 & $28 \%$ & $31 \%$ & $49 \%$ & $58 \%$ & $49 \%$ & $25 \%$ \\
\hline Case 2 & $38 \%$ & $39 \%$ & $48 \%$ & $58 \%$ & $52 \%$ & $25 \%$ \\
\hline Case 3 & $32 \%$ & $33 \%$ & $40 \%$ & $46 \%$ & $43 \%$ & $34 \%$ \\
\hline Case 4 & $38 \%$ & $42 \%$ & $59 \%$ & $65 \%$ & $58 \%$ & $38 \%$ \\
\hline Case 5 & $46 \%$ & $49 \%$ & $58 \%$ & $65 \%$ & $62 \%$ & $37 \%$ \\
\hline
\end{tabular}




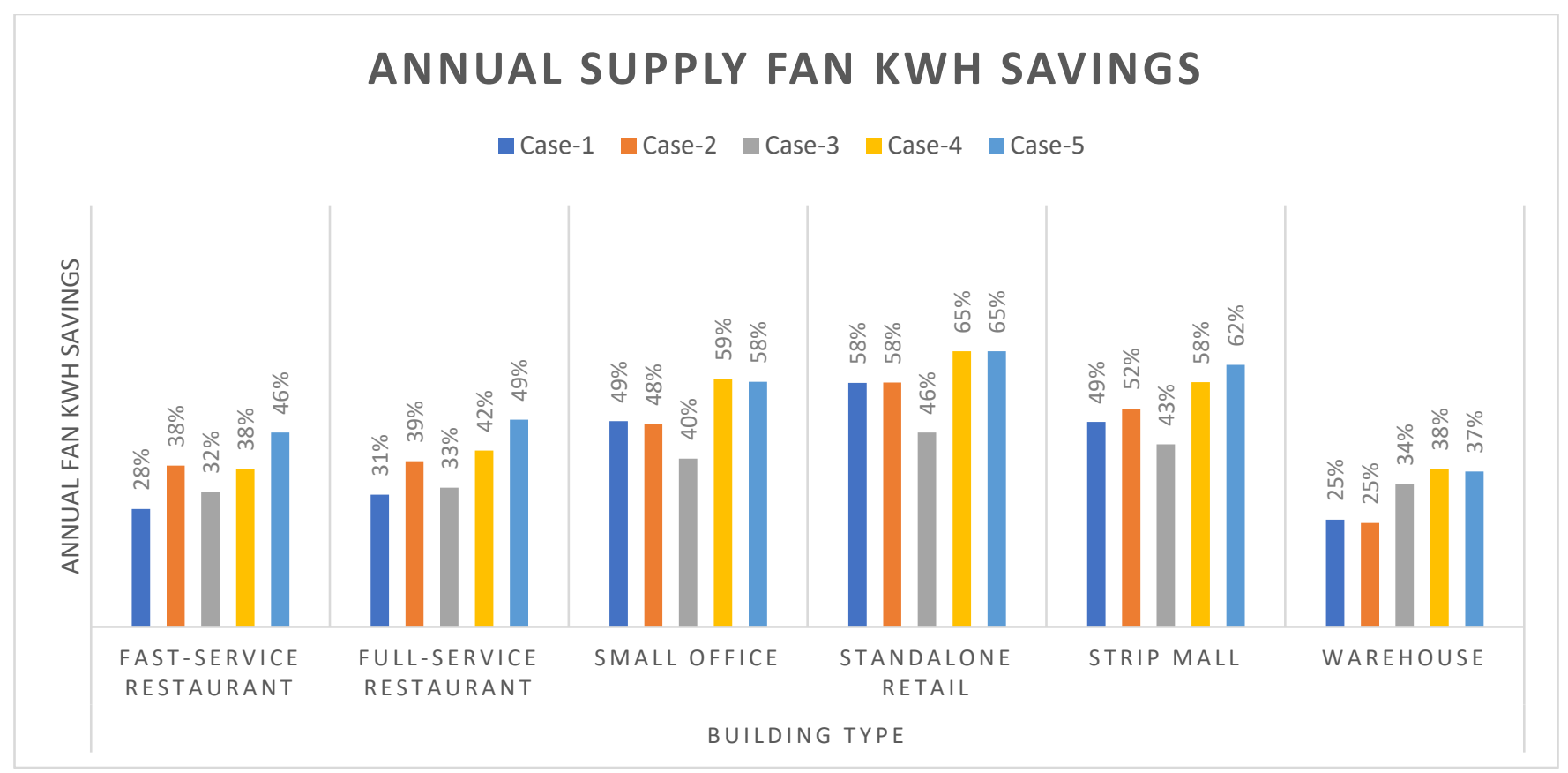

Figure 5. Annual fan electricity savings

Table 13. Normalized Annual Fan Electricity Savings in kWh/BHP

\begin{tabular}{lllllll}
\hline \multicolumn{7}{c}{ Fan Energy Savings in kWh/BHP } \\
\hline $\begin{array}{l}\text { Case } \\
\text { Type }\end{array}$ & $\begin{array}{l}\text { Fast-Service } \\
\text { Restaurant }\end{array}$ & $\begin{array}{l}\text { Full-Service } \\
\text { Restaurant }\end{array}$ & $\begin{array}{l}\text { Small } \\
\text { Office }\end{array}$ & $\begin{array}{l}\text { Stand-Alone } \\
\text { Retail }\end{array}$ & $\begin{array}{l}\text { Strip } \\
\text { Mall }\end{array}$ & Warehouse \\
\hline Case 1 & 1,524 & 1,713 & 1,247 & 2,401 & 2,221 & 983 \\
\hline Case 2 & 2,086 & 2,143 & 1,230 & 2,405 & 2,367 & 954 \\
\hline Case 3 & 1,749 & 1,802 & 1,020 & 1,915 & 1,978 & 1,310 \\
\hline Case 4 & 2,045 & 2,284 & 1,504 & 2,713 & 2,652 & 1,450 \\
\hline Case 5 & 2,512 & 2,685 & 1,486 & 2,714 & 2,842 & 1,426 \\
\hline
\end{tabular}




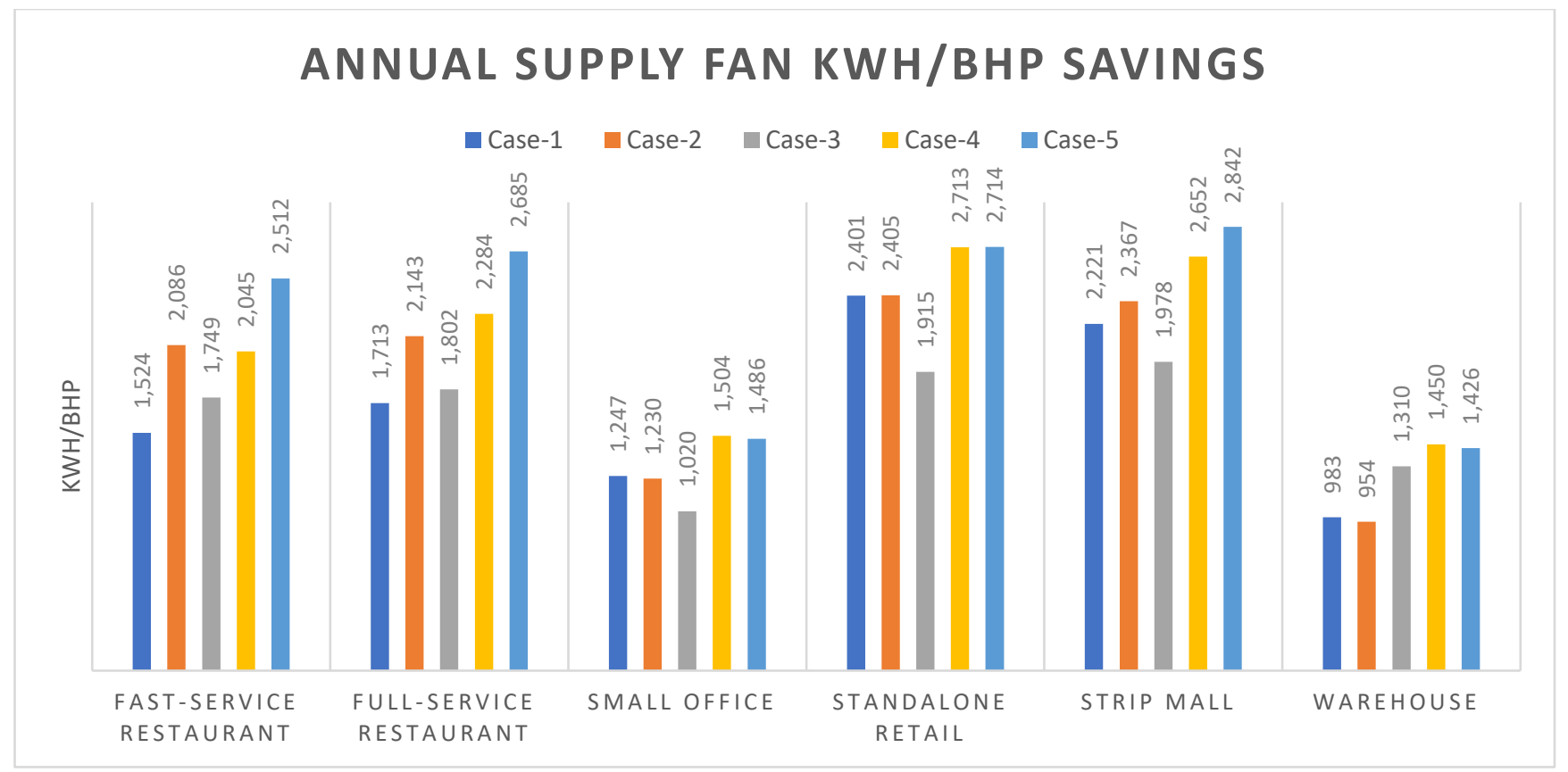

Figure 6. Normalized annual fan electricity savings in kWh/BHP

\subsection{Peak kW Demand Reduction}

Table 14 and Figure 7 show peak energy demand savings for each building type. The savings predicted ranged from $0 \%$ for warehouse to $10 \%$ for small office building types. The normalized peak $\mathrm{kW}$ savings ranged from $0 \mathrm{~W} / \mathrm{ft}^{2}-1.1 \mathrm{~W} / \mathrm{ft}^{2}$. In terms of normalized $\mathrm{kW}$ savings per ton, savings as high as $0.2 \mathrm{~kW} /$ ton were observed for the small office building type. Only hours between 1 p.m. -5 p.m., Monday to Friday, June through August were considered for peak savings calculation (Illinois Statewide Technical Reference Manual 2019). As expected, Case 5 resulted in the highest energy demand savings for all the building types considered. Use of supply fan SRMs contributed to the peak energy savings both from improved part-load performance and motor efficiency. The normalized peak savings in $\mathrm{W} / \mathrm{ft}^{2}$ and $\mathrm{W} /$ ton are shown in Table 15. The savings ranged from $0-1.1 \mathrm{~W} / \mathrm{ft}^{2}$ and from $0-199 \mathrm{~W} /$ ton.

Table 14. Peak kW Savings

\begin{tabular}{lllllll}
\hline $\begin{array}{l}\text { Case } \\
\text { Type }\end{array}$ & $\begin{array}{l}\text { Fast-Service } \\
\text { Restaurant }\end{array}$ & $\begin{array}{l}\text { Full-Service } \\
\text { Restaurant }\end{array}$ & $\begin{array}{l}\text { Small } \\
\text { Office }\end{array}$ & $\begin{array}{l}\text { Stand-Alone } \\
\text { Retail }\end{array}$ & Strip Mall & Warehouse \\
\hline Case 1 & $0 \%$ & $0 \%$ & $1 \%$ & $2 \%$ & $2 \%$ & $0 \%$ \\
\hline Case 2 & $5 \%$ & $5 \%$ & $8 \%$ & $9 \%$ & $7 \%$ & $0 \%$ \\
\hline Case 3 & $3 \%$ & $2 \%$ & $1 \%$ & $4 \%$ & $0 \%$ & $1 \%$ \\
\hline Case 4 & $2 \%$ & $2 \%$ & $2 \%$ & $4 \%$ & $4 \%$ & $1 \%$ \\
\hline Case 5 & $7 \%$ & $7 \%$ & $10 \%$ & $11 \%$ & $9 \%$ & $1 \%$ \\
\hline
\end{tabular}




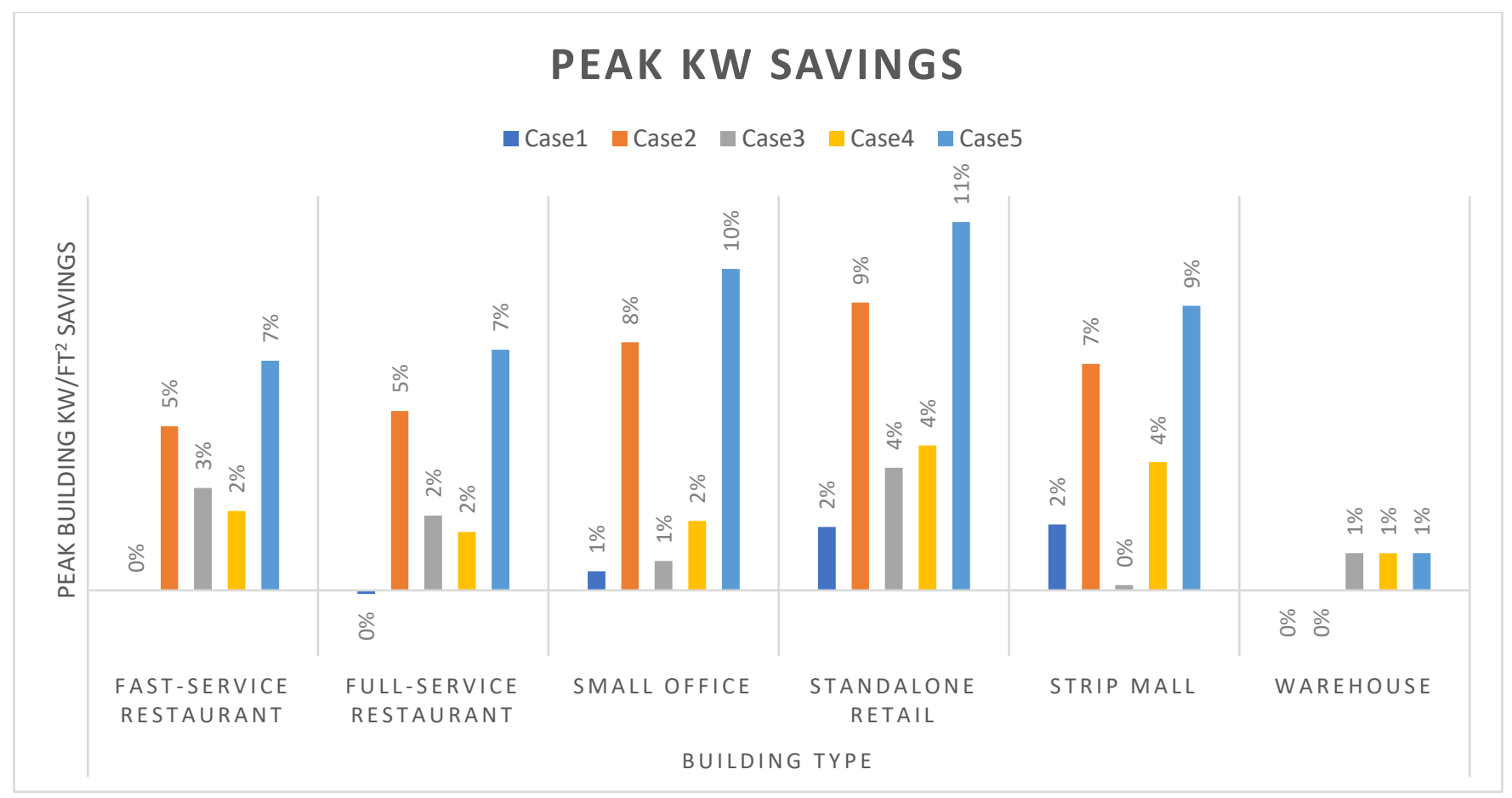

Figure 7. Peak kW savings

Table 15. Normalized Peak Energy Demand Savings in W/ft ${ }^{2}$ and W/ton

\begin{tabular}{|c|c|c|c|c|c|c|}
\hline & & Case 1 & Case 2 & Case 3 & Case 4 & Case 5 \\
\hline \multirow{2}{*}{$\begin{array}{l}\text { Fast-Service } \\
\text { Restaurant }\end{array}$} & $\left(W / f^{2}{ }^{2}\right)$ & 0.0 & 0.8 & 0.5 & 0.4 & 1.1 \\
\hline & (W/Ton) & 0.1 & 95.1 & 59.3 & 45.9 & 133.0 \\
\hline \multirow{2}{*}{$\begin{array}{l}\text { Full-Service } \\
\text { Restaurant }\end{array}$} & $\left(W / f^{2}{ }^{2}\right)$ & 0.0 & 0.6 & 0.3 & 0.2 & 0.9 \\
\hline & (W/Ton) & 0 & 107.5 & 44.8 & 35.1 & 144.2 \\
\hline \multirow[t]{2}{*}{ Small Office } & $\left(W / f^{2}{ }^{2}\right)$ & 0.0 & 0.2 & 0.0 & 0.1 & 0.3 \\
\hline & (W/Ton) & 11.9 & 153.4 & 18.1 & 42.9 & 198.9 \\
\hline \multirow{2}{*}{$\begin{array}{l}\text { Stand-Alone } \\
\text { Retail }\end{array}$} & $\left(W / f^{2}\right)$ & 0.1 & 0.3 & 0.1 & 0.2 & 0.4 \\
\hline & (W/Ton) & 29.0 & 131.6 & 56.1 & 66.2 & 168.5 \\
\hline \multirow[t]{2}{*}{ Strip Mall } & $\left(W / \mathrm{ft}^{2}\right)$ & 0.1 & 0.3 & 0.0 & 0.2 & 0.4 \\
\hline & (W/Ton) & 33.2 & 113.8 & 2.6 & 64.3 & 142.9 \\
\hline \multirow[t]{2}{*}{ Warehouse } & $\left(W / f^{2}{ }^{2}\right)$ & 0.0 & 0.0 & 0.01 & 0.01 & 0.01 \\
\hline & (W/Ton) & 0 & 0 & 40.6 & 40.6 & 40.6 \\
\hline
\end{tabular}




\section{Conclusion}

The simulation results predict considerable annual energy savings for all the upgrade scenarios. The following energy-saving ranges were observed:

- Annual total building energy savings from $3 \%-23 \%$

- Annual total building energy savings from $0.1 \mathrm{kWh} / \mathrm{ft}^{2}-7.6 \mathrm{kWh} / \mathrm{ft}^{2}$

- Annual total building energy savings from $364 \mathrm{kWh} / \mathrm{ton}-1,146 \mathrm{kWh} / \mathrm{ton}$

- Annual HVAC energy savings ranging from $23 \%-53 \%$

- Annual supply fan energy savings ranging from $25 \%-65 \%$

- Annual supply fan energy savings ranging from $954 \mathrm{kWh} / \mathrm{BHP}-2,842 \mathrm{kWh} / \mathrm{BHP}$

- Peak energy demand savings from $0 \%-11 \%$

- Peak energy demand savings from $0 \mathrm{~W} / \mathrm{ft}^{2}-1.1 \mathrm{~W} / \mathrm{ft}^{2}$

- Peak energy demand savings from $0 \mathrm{~W} /$ ton-198 W/ton.

As expected, RTUs with a variable-speed compressor (Case 2 and Case 5) showed superior performance compared to RTUs with single-stage and two-stage compressor. This is a result of enhanced part-load performance due to the improved matching of the compressor capacity with the cooling load.

Similarly, supply fans with SRMs exhibited improved performance compared to the constant- and variable-speed induction motor supply fan cases examined. In all building types, the use of SRMs on the RTU supply fans resulted in $9 \%$ extra fan energy savings on average, compared to the supply fan with a variable-speed induction motor. 


\section{References}

ASHRAE (2016). ANSI/ASHRAE/IES-90.1-2016: Energy Standard for Buildings Except Low-Rise Residential Buildings. Atlanta, Georgia: ASHRAE.

Cai, J., Braun, J.E., (2018). Assessments of variable-speed equipment for packaged rooftop units (RTUs) in the United States. Energy Build. 164, 203-218. https://doi.org/10.1016/j.enbuild.2018.01.007

DOE (2018). EnergyPlus Version 8.9.0 Documentation: Engineering Reference. https://energyplus.net/sites/all/modules/custom/nrel_custom/pdfs/pdfs_v8.9.0/EngineeringReference.pdf

DOE (2020). "EnergyPlus." Accessed October 29, 2020. https://energyplus.net/.

DOE (2020). "EnergyPlus Weather Data." Accessed October 29, 2020. https://energyplus.net/weather.

Illinois Statewide Technical Reference Manual (2019). 2019 Illinois Statewide Technical Reference Manual for Energy Efficiency Version 7.0 Volume 1: Overview and User Guide.

https://s3.amazonaws.com/ilsag/IL-TRM_Effective_010119_v7.0_Vol_1-

4_Compiled_092818_Final.pdf.

SCE (2018). Software-Controlled Switch Reluctance Motors. Emerging Technologies Coordinating Council. https://www.etcc-ca.com/reports/software-controlled-switch-reluctance-motors.

Studer, Daniel, Rachel Romero, Lesley Herrmann, and Kyle Benne (2012). Energy Implications of Retrofitting Retail Sector Rooftop Units with Stepped-Speed and Variable-Speed Functionality. Golden, CO: NREL. NREL/TP-5500-51102. https://www.nrel.gov/docs/fy12osti/51102.pdf.

U.S. Energy Information Administration (2012). "2012 Commercial Buildings Energy Consumption Survey." Accessed October 29, 2020. https://www.eia.gov/consumption/commercial/.

Wheeler, Grant, Eric Kozubal, and Ron Judkoff (2018). Experimental Design and Laboratory Characterization of a Medium- and High-Efficiency Rooftop Unit for Use in Building Energy Simulations. Golden, CO: NREL. NREL/CP-5500-71133. https://www.osti.gov/biblio/1558884experimental-design-laboratory-characterization-medium-high-efficiency-rooftop-unit-use-buildingenergy-simulations. 


\section{Appendix A. Details of RTU Operation Modes}

Figure A-1 through Figure A-8 show the modes of operation for the different cases considered. The figures show how the modes of operation vary from case to case, as well as when outdoor air is appropriate and not appropriate for economizer operation.

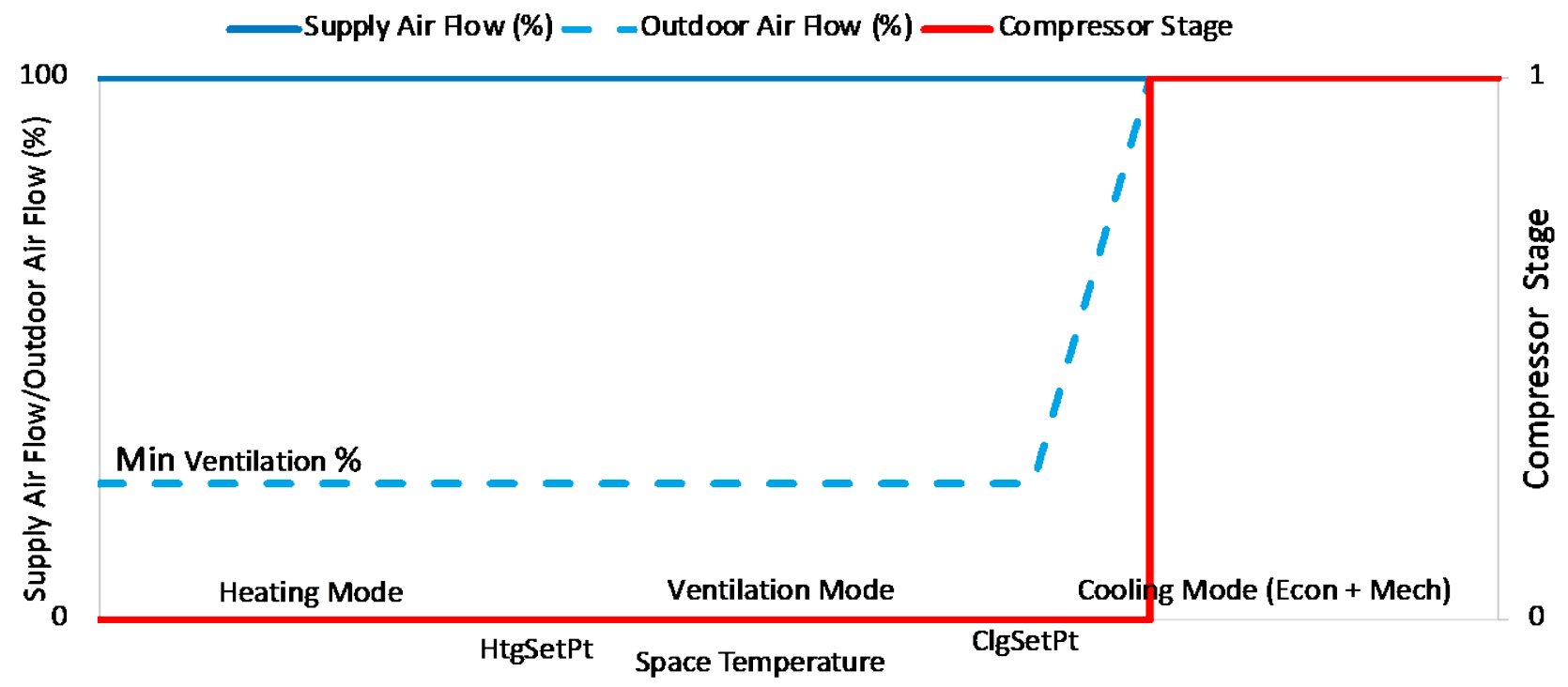

Figure A-1. Sequence of operations for baseline when outdoor air temperature is appropriate for economizer operation

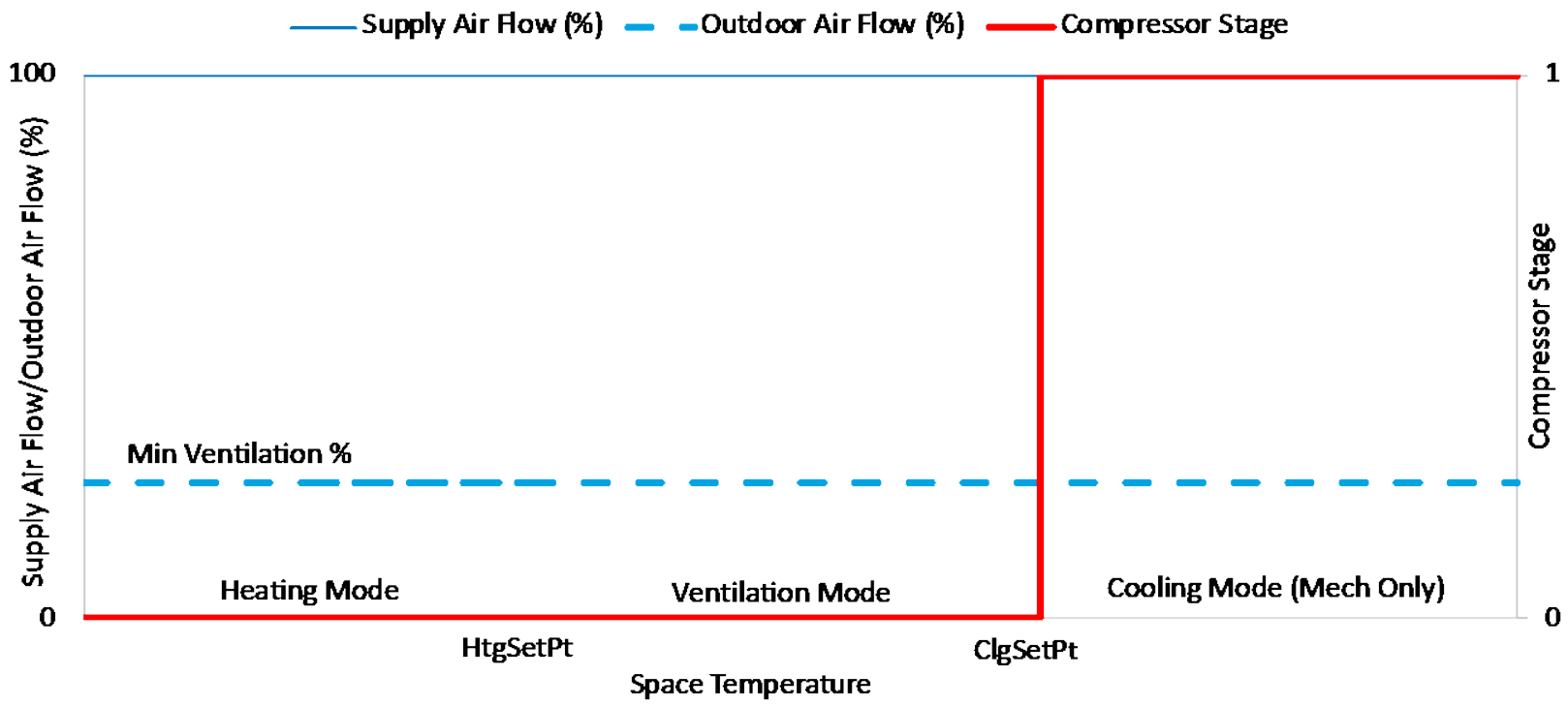

Figure A-2. Sequence of operations for baseline when outdoor air temperature is not appropriate for economizer operation 


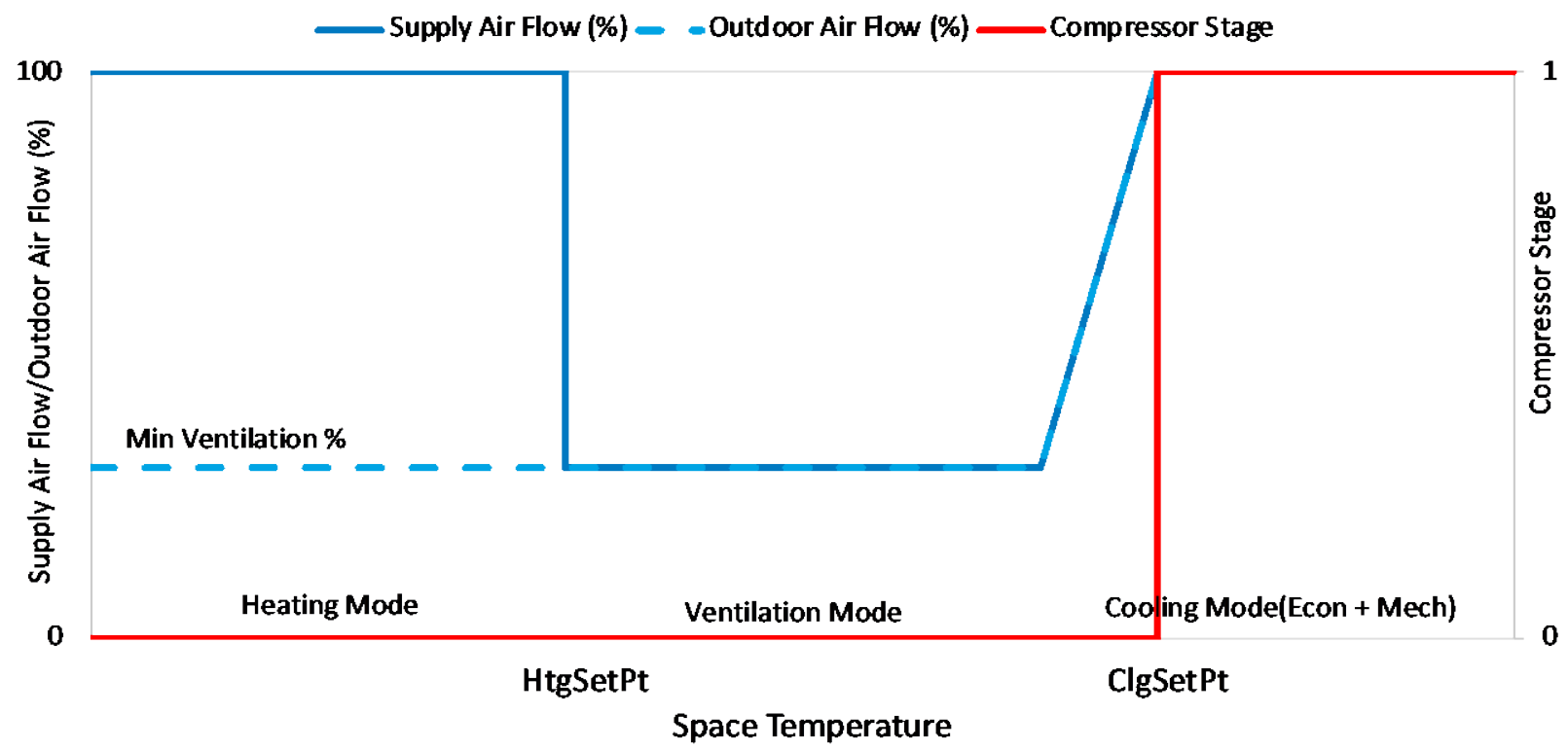

Figure A-3. Sequence of operations for Case 3 when outdoor air temperature is appropriate for economizer operation

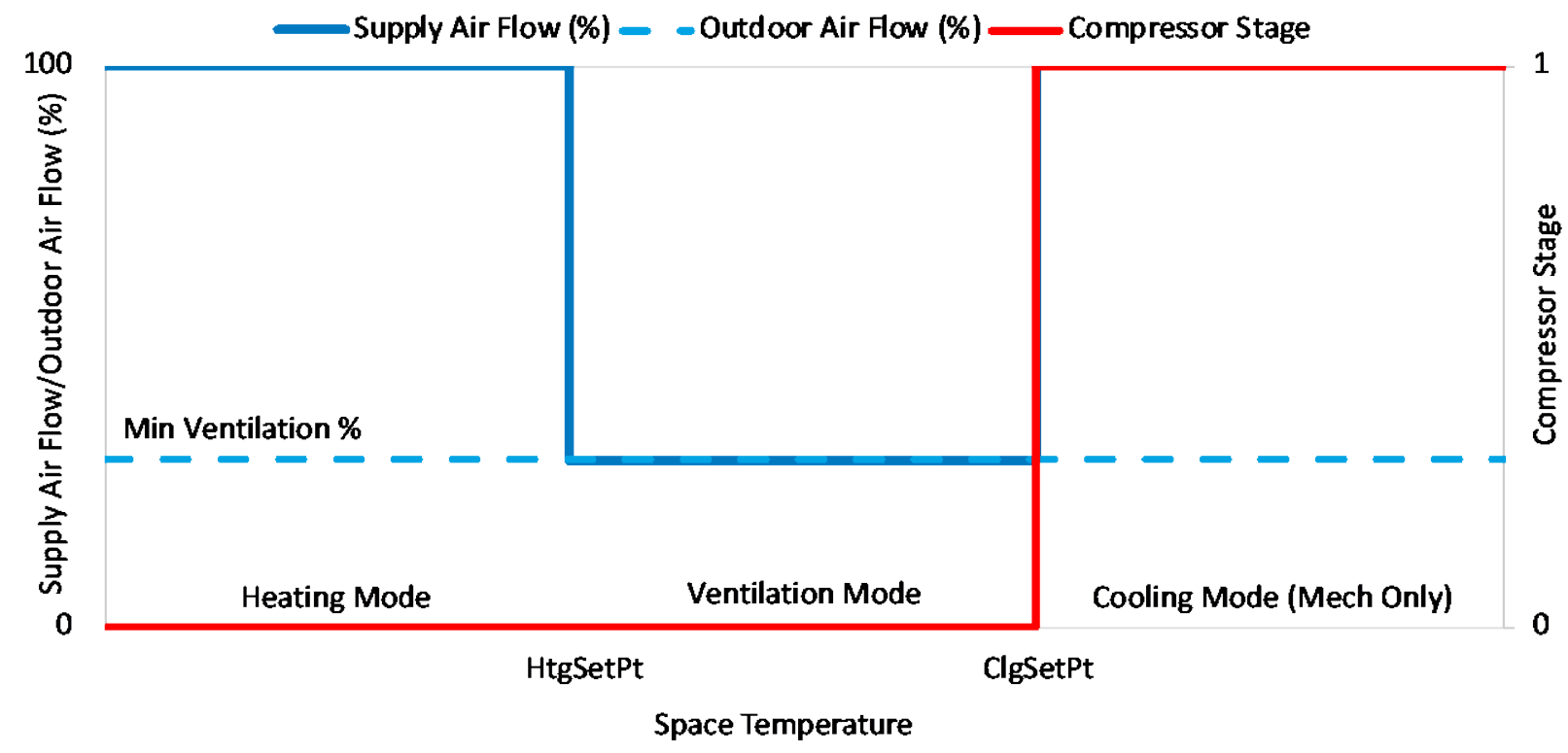

Figure A-4. Sequence of operations for Case 3 when outdoor air temperature is not appropriate for economizer operation 


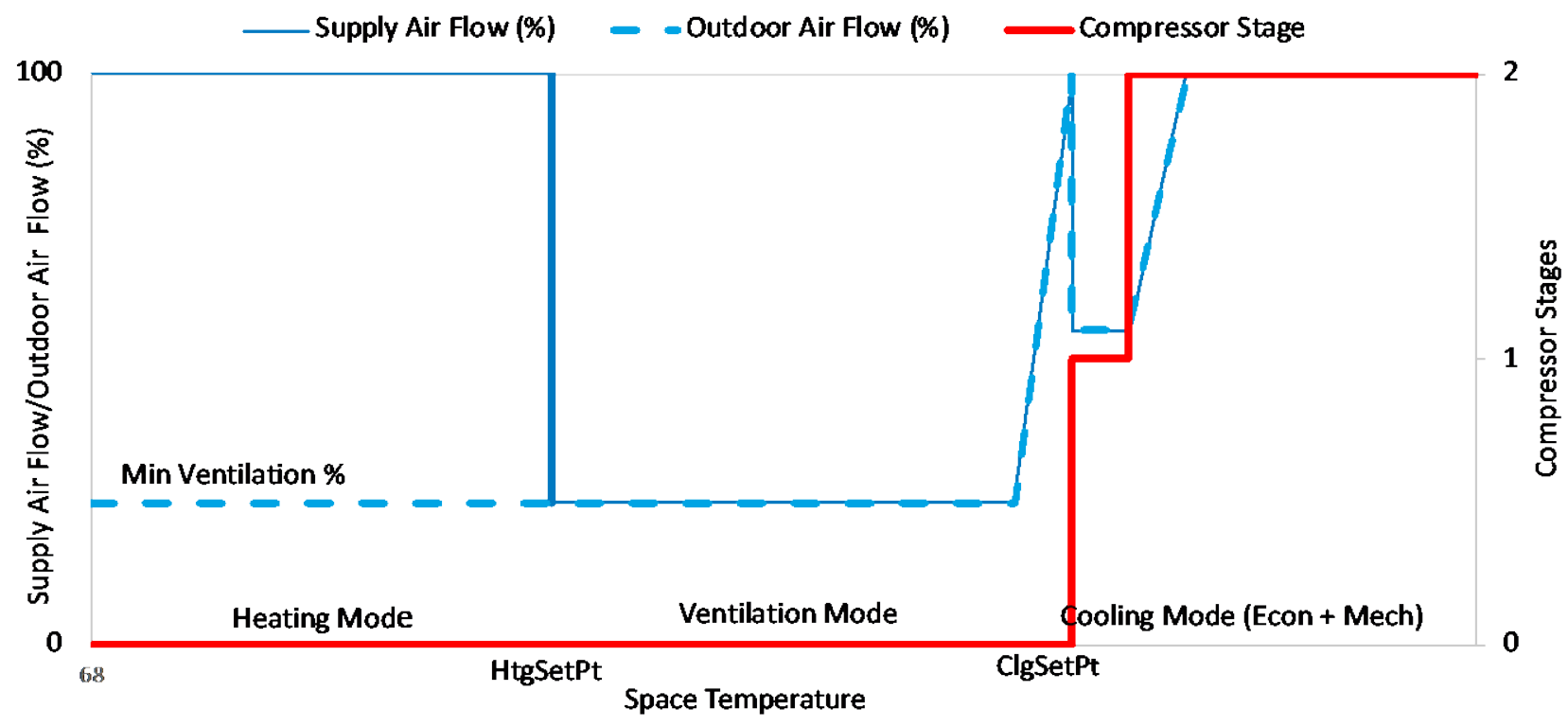

Figure A-5. Sequence of operations for Case 1 and Case 4 when outdoor air temperature is appropriate for economizer operation

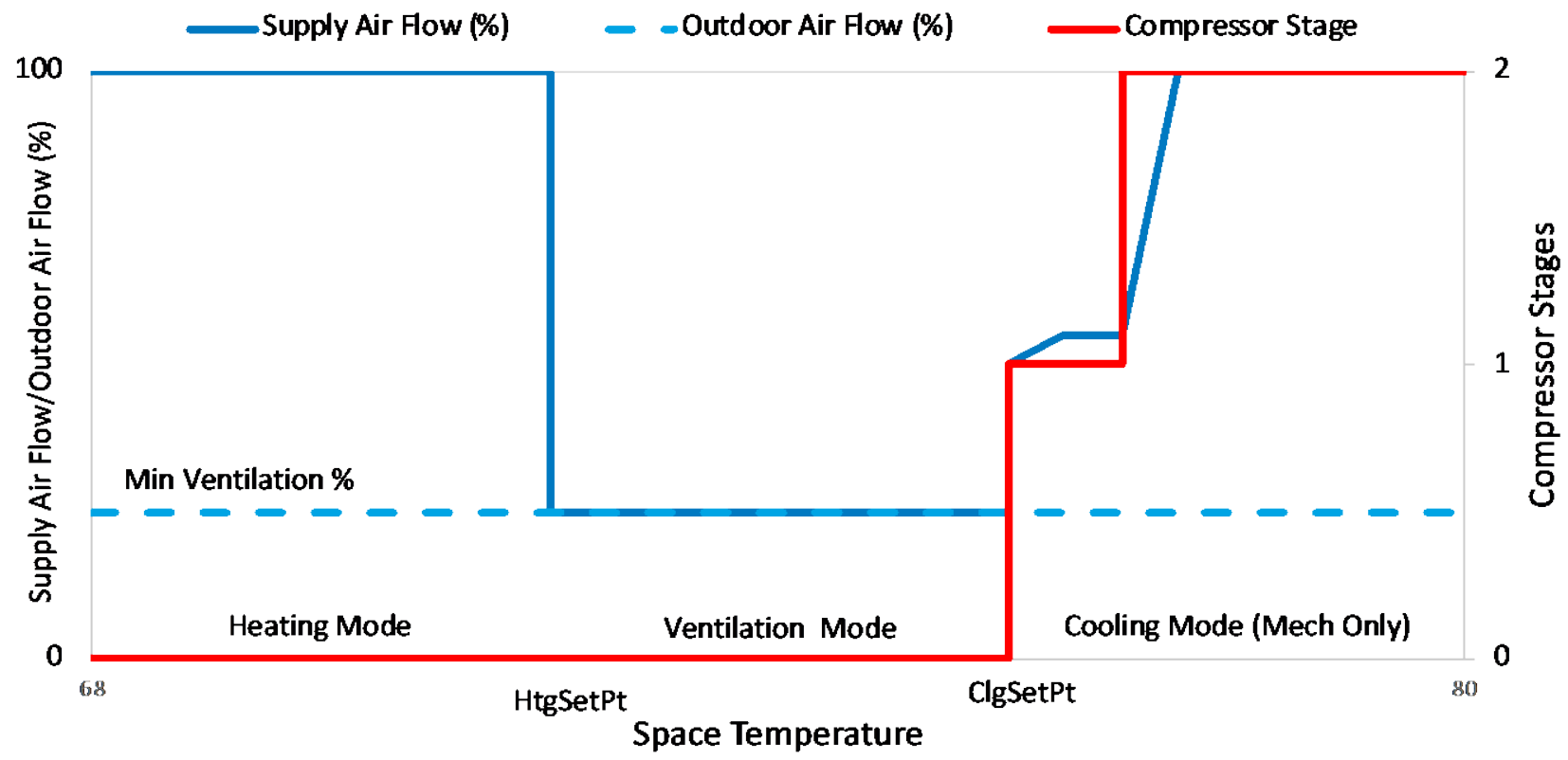

Figure A-6. Sequence of operations for Case 1 and Case 4 when outdoor air temperature is not appropriate for economizer operation 


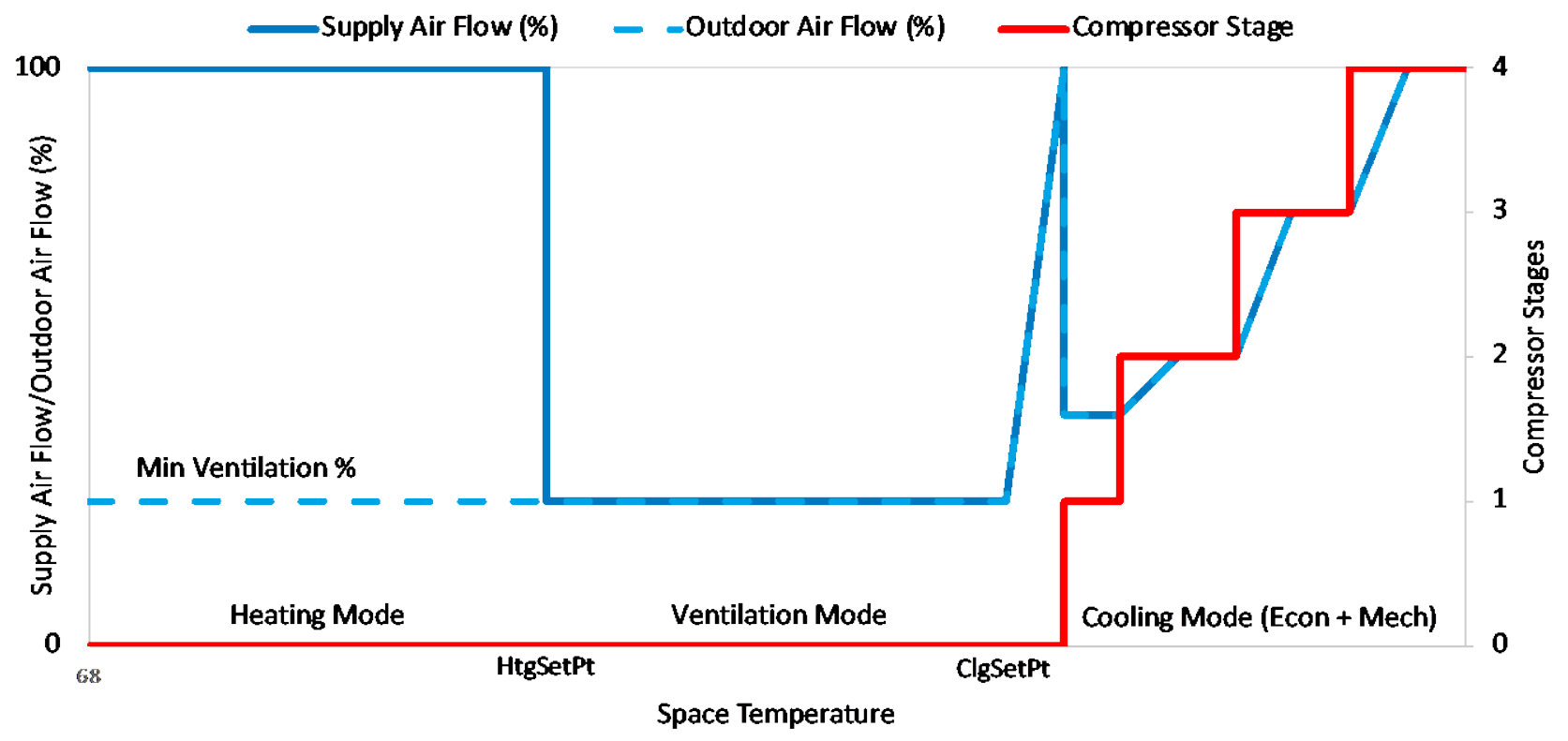

Figure A-7. Sequence of operations for Case 2 and Case 5 when outdoor air temperature is appropriate for economizer operation

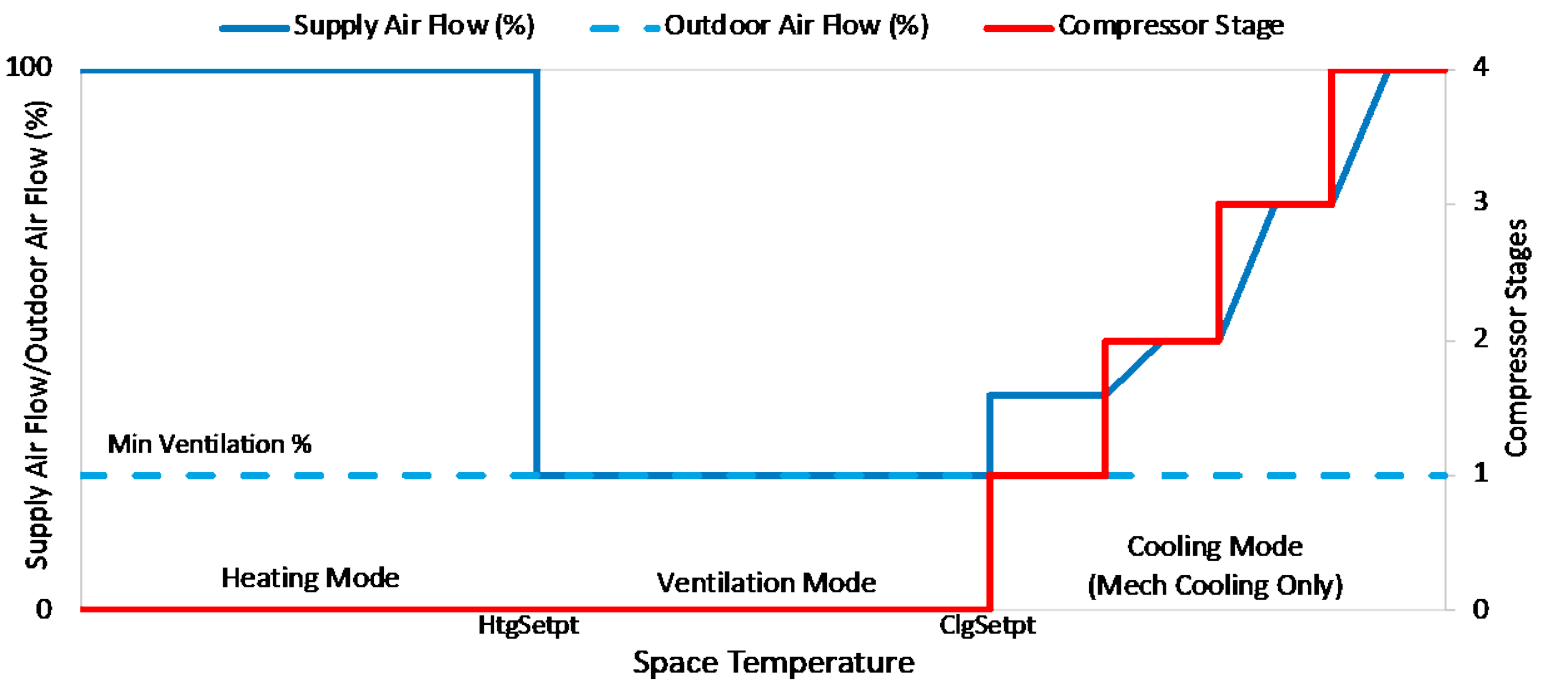

Figure A-8. Sequence of operations for Case 2 and Case 5 when outdoor air temperature is not appropriate for economizer operation 